\title{
Speciation analysis by small-bore HPLC coupled to ICPMS
}

M. Grotti ${ }^{(a)}$, A. Terol ${ }^{(a)}$, J.L. Todolí ${ }^{(b) *}$

(a) Department of Chemistry and Industrial Chemistry, Univeristy of Genoa, Via Dodecaneso 31, 16146 Genova, Italy

(b) Department of Analytical Chemistry, Nutrition and Food Science, University of Alicante, P.O. Box 99, 03080 Alicante, Spain

\begin{abstract}
Although HPLC-ICPMS has established itself as the analytical technique of choice for elemental speciation analysis, there are some remaining limitations, mainly concerning post-column dispersion effects and the degradation of the ICP stability and ionization efficiency due to organic or saline mobile phases. The application of small-bore columns in conjunction with low dead-volume interfaces proved very useful for overcoming these problems, since they can provide lower matrix load and reduced peak dispersion, along with minimization of sample size and solvent consumption, faster chromatographic separations, better resolution and sensitivity.

Since, more work is expected to be reported in this area, we review recent research in the field of speciation analysis by small-bore HPLC coupled to ICPMS, with the emphasis on significant advances in methods and instrumentation, relevant applications and current limitations.
\end{abstract}

Keywords: Speciation; Narrow-bore; Micro-bore; Nano-bore; Inductively coupled plasma mass spectrometry; UHPLC;

*Corresponding author. Tel. +34 965909775; Fax: +34 965903697. Email: jose.todoli@ua.es 


\section{Article outline}

1. Introduction

2. Instrumental aspects

2.1 Chromatographic system

\subsubsection{Column dimensions}

2.1.2 Stationary and mobile phases

\subsection{Interfaces}

2.2.1 Micronebulizers/spray chambers

2.2.2 Direct injection nebulizers

2.2.3 Additional systems

2.3. Effect of the mobile phase on ICPMS signal

3. Analytical performances

3.1 Retention times, resolution and efficiency

3.2 Sensitivity and limits of detection

\subsection{Column recovery}

4. Applications

5. Future trends

Abbreviations: AB, arsenobetaine; AF, Affinity chromatography; AsIII, Arsenite; AsV, Arsenate; Cd-MTs, cadmium metallothioneins; CrIII, trivalent chromium; CrVI, hexavalent chromium; $\mathrm{Cu}-$ MTs, copper metallothioneins; DIHEN, Direct injection high efficiency nebulizer; DIN, Direct Injection Nebulizer; DMA, Dimethylarsinate; GP, Gel permeation chromatography; GPx, Glutathione peroxidase; HEN, High efficiency nebulizer; HILIC, Hydrophilic interaction liquid chromatography; HPLC, High performance liquid chromatography; ICPMS, Inductively coupled plasma mass spectrometry; IP-RP, Ion pairing - reversed phase; MA, Methylarsonate; MCN, Microconcentric nebulizer; MD, Membrane desolvation; MeSeCys, Methylselenocysteine; MeSeMet, 
Methylselenomethionine; OCN, Oscillating capillary nebulizer; p-ASA, p-arsanilic acid; PDC, 2,6pyridinedicarboxylic acid; RP, reverse-phase chromatography; SeIV, selenite; SeVI, selenite; Se-AA, Selenoamino acids; SeAlb, seleno-albumin; SEC, Size exclusion chromatography; SeGaba, Selenogammaaminobutyric acid; SelP, Selenoprotein P; SeMet, Selenomethionine; SF, Sector field; TBAH, tetrabutylammonium hydroxide; TMSe, Trimethylselenonium ion; UHPLC, Ultra high performance liquid chromatography; Zn-MTs, zinc metallothioneins; ICPMS instrument: CRC, Collision/reaction cell; Q, Quadrupole; SF, Sector field (HR, high resolution; LR, low resolution; MR, medium resolution); 4-OH, 4-hydroxyphenylarsonic acid. 


\section{Introduction}

Speciation analysis, defined as the determination of one or more individual chemical species of an element in a sample [1], has grown considerably in recent years and it is now recognised as a major analytical field. In fact, this area of Analytical Chemistry has become an important and demanding issue in several research fields, including green chemistry, eco- and clinical toxicology, medical and nutrition science, food and petrochemical industries, for the reason that the toxicity and reactivity of trace elements strongly depend on their chemical form [2]. For instance, trivalent chromium plays an essential role in the glucose metabolism, while hexavalent chromium is highly toxic and carcinogenic $[3]$.

Therefore, a sensitive and selective technique able to discriminate among species is required. Nowadays, the coupling of high performance liquid chromatography (HPLC) with inductively coupled plasma mass spectrometry (ICPMS) is recognised as the most effective and widely employed instrumental technique for speciation analysis [4-6]. In fact, liquid chromatography is continuously improving and it offers a very rich tool-box for separating the species of interest - including ion exchange, reverse-phase (RP), ion-pairing reverse-phase (IP-RP) and size-exclusion (SEC) chromatography - while ICPMS allows accurate and sensitive quantification of the eluted compounds. Although the HPLC-ICPMS coupling is generally straightforward, a closer look into this hyphenated system highlighted some potential limitations, such as (i) possible metal contamination deriving from the chromatographic system (pump, valve, tubing) or the stationary and mobile phases, (ii) post-column dispersion effects due to the sample introduction system used as the interface between HPLC and ICPMS and (iii) degradation of the stability and ionization efficiency of the ICP source due to the solvent plasma load, especially in the case of organic mobile phases.

In order to solve the detrimental effects associated to the introduction of high amounts of organic solvents or salts into the plasma, low mobile phase flow rates (e.g., on the order of several tens of microliters per minute) can be employed. In this case, the column dimensions as well as 
stationary phase characteristics must be adapted. Small-bore columns are then employed [7]. This miniaturization offers several advantages, such as: (i) lower matrix plasma load; (ii) reduced (up to 100-fold) consumption of mobile phase and consequently, waste minimization [8]; (iii) faster chromatographic separations; (iv) better resolution [7] and (v) improved sensitivity, due to the higher sample introduction efficiency and lower solvent load [9]. In contrast, some reports indicate that small-bore columns do not incorporate significant advantages. For example, Stefánka et al. [10] found no improvement of chromatographic resolution, peak width or sensitivity when working with $2.1,1.0$ and $0.32 \mathrm{~mm}$ i.d. columns.

There has been a growing interest in the application of small-bore HPLC-ICPMS in the speciation analysis field. Not surprisingly, the most investigated elements were arsenic [11-19] and selenium [13-14, 20-30]. Other important studies dealt with the speciation analysis of potentially toxic elements, such as $\mathrm{Cr}[3,8,31-32], \mathrm{Hg}$ [33-37], $\mathrm{Pb}[33,35]$ and $\mathrm{Sn}$ [7], or the identification/quantification of biologically-active compounds, such as metallothioneins (MTs) [3842], cobalamins [35, 43-44] and phosphopeptides [45-47].

In 1997, Garraud et al. [9] reviewed the use of small-bore columns coupled to atomic spectrometry. Considering that significant amount of work has been performed since then and that further research is expected in this promising field of Analytical Chemistry, the main objective of the present paper is to review the use of small-bore columns in HPLC coupled to ICPMS for the elemental speciation, with the special emphasis on the recently achieved results and the remaining limitations.

\section{Instrumental aspects}

Provided that ICPMS is tuned for optimal sensitivity and robustness, the critical points of HPLCICPMS coupling concern the chromatographic system and the interface design.

\subsection{Chromatographic system}




\subsubsection{Column dimensions}

Typically, the most important dimensions of chromatographic columns are the length, inner diameter and stationary phase particle diameter.

The column length has a direct effect on peak separation. Thus, an increase in this dimension gives rise to an enhancement in the number of theoretical plates whereas the longer the column the more significant the peak dispersion. For example, selenoamino acids were separated on the multimode gel filtration GS320A-M8E column while the same separation on the shorter (and narrower) GS320A-M5D column was not effective [21]. On the other hand, the separation of $\mathrm{Hg}$ (II), $\mathrm{MeHg}^{+}$ and $\mathrm{PhHg}^{+}$by reversed phase micro-HPLC was achieved using a 100-mm length ODS column while coelution between the first two compounds was observed with a 150-mm length column [34].

The column inner diameter is another factor to take into account. However, the development of new columns made the situation to be more complex. Thus, for instance, the modification in the column format from cylindrical to columns with square section implies that the column diameter is not enough for describing its geometry. Furthermore, the geometry of the stationary phase has evolved thus leading to the introduction of monolithic columns or to the so-called fused core particles. This fact has led to consider the particle diameter as an obsolete dimension. Nevertheless, the columns usually employed in the field of elemental speciation are cylindrical, what makes it possible to propose a classification such as that indicated in Table $1[10,26]$.

Table 1. Classification of the columns according to their inner diameter. Adapted from ref. [48]

\begin{tabular}{|c|c|c|}
\hline Description & Dimension & $\begin{array}{c}\text { Approximate typical flow rate at a } \\
\text { velocity from } \mathbf{1} \text { to } \mathbf{1 0 ~} \mathbf{~ m m} / \mathbf{s}\end{array}$ \\
\hline Open tubular & $<25 \mu \mathrm{m} \mathrm{id}$ & $<25 \mathrm{~nL} \mathrm{~min}^{-1}$ \\
\hline Nano-bore column & $25 \mu \mathrm{m} \leq \mathrm{id} \leq 100 \mu \mathrm{m}$ & $25-4000 \mathrm{~nL} \mathrm{~min}^{-1}$ \\
\hline Capillary column & $100 \mu \mathrm{m}<\mathrm{id}<1 \mathrm{~mm}$ & $0.4-200 \mu \mathrm{L} \mathrm{min}^{-1}$ \\
\hline
\end{tabular}




\begin{tabular}{|c|c|c|}
\hline Micro-bore column & $1 \mathrm{~mm} \leq \mathrm{id} \leq 2.1 \mathrm{~mm}$ & $50-1000 \mu \mathrm{L} \mathrm{min}^{-1}$ \\
\hline Narrow-bore column & $2.1 \mathrm{~mm}<\mathrm{id}<4 \mathrm{~mm}$ & $0.3-3 \mathrm{~mL} \mathrm{~min}^{-1}$ \\
\hline Normal-bore column & $4 \mathrm{~mm} \leq \mathrm{id} \leq 5 \mathrm{~mm}$ & $1-10 \mathrm{~mL} \mathrm{~min}^{-1}$ \\
\hline
\end{tabular}

The reduction in the column diameter incorporated by small-bore columns while keeping constant the stationary phase particle diameter causes a concomitant reduction in the column dead volume. This variable can take typical values going from 200 to $1000 \mu \mathrm{l}$ for small bore and conventional columns, respectively. Moreover, as it is stated, frictional (Joule) heating is more easily dissipated when working with columns having low diameters than for conventional ones [49] due to their higher surface area to volume ratio. As a result, lower analyte dispersion is produced, thus increasing the detectability by a factor close to one order of magnitude.

Finally, the particle diameter of the stationary phase used in small-bore HPLC-ICPMS ranged from 1.7 to $13 \mu \mathrm{m}$, with typical values of $3-5 \mu \mathrm{m}$. Obviously, the lower the particle size, the higher the chromatographic efficiency and the back pressure required to maintain a given liquid flow rate. This led to the development of a new technique, called "Ultra High Performance Liquid Chromatography" (UHPLC), characterized by the use of sub-2 $\mu \mathrm{m}$ particles and pressures higher than 20,000 psi.

\subsubsection{Stationary and mobile phases}

Organic species containing a metal or metalloid can be separated according to several chromatographic mechanisms. The present section describes the methods mostly exploited to separate these species using small-bore columns coupled to ICPMS.

Reversed Phase Chromatography (RP) and Ion Pairing Reversed Phase Chromatography (IP-RP) 
RPC is one of the most commonly applied chromatographic techniques because of the large choice of eluents that allows the separation of numerous elemental species. The most common RP small bore columns coupled to ICPMS have been $\mathrm{C} 18$ and C8, although C4 columns have also been used. The mobile phases in RP chromatography are often aqueous solutions mixed with organic solvents such as methanol, ethanol or acetonitrile. While initially, anion exchange small-bore columns were the most popular to separate chromium, arsenic and selenium species [9], with the introduction of the socalled IP-RP chromatography, it was also possible to separate polar substances on a RP column. This technique is based on the addition of a counter ion to the mobile phase in order to promote the formation of ion-pairs with polar analytes that can be retained on a RP column. Table 2 shows the main counter ions used with small-bore columns.

Table 2. Studied species, ion pair reagents, stationary and mobile phase used in speciation studies with small-bore columns coupled to ICPMS.

\begin{tabular}{|l|l|l|l|l|}
\hline Studied species & Ion pairing reagents & $\begin{array}{l}\text { Stationary } \\
\text { phase }\end{array}$ & Mobile phase & Ref. \\
\hline $\begin{array}{l}\mathrm{Et}_{3} \mathrm{~Pb}^{+}, \mathrm{Ph}_{3} \mathrm{~Pb}^{+}, \mathrm{MeHg}^{+}, \mathrm{EtHg}^{+} \\
\text {and } \mathrm{PhHg}^{+}\end{array}$ & Sodium pentanesulfonate & $\mathrm{C} 8$ & $20 \% \mathrm{ACN}$ & {$[35]$} \\
\hline $\begin{array}{l}\text { MeSeCys, SeGaba, TMSe, } \\
\text { MeSeMet, SeMet }\end{array}$ & $\begin{array}{l}\text { Perfluorinated carboxylic } \\
\text { acids }\end{array}$ & $\mathrm{C} 8$ & $20 \% \mathrm{MeOH}$ & {$[20]$} \\
\hline $\mathrm{SeCys}^{\mathrm{SeMet}, \mathrm{SeCA} \text { and } \mathrm{SeEt}}$ & Heptafluorobutyric acid & $\mathrm{C} 18$ & $30 \% \mathrm{MeOH}$ & {$[28]$} \\
\hline $\begin{array}{l}\mathrm{Hg}^{2+}, \mathrm{MeHg}^{+}, \mathrm{EtHg}^{+}, \mathrm{PhHg}^{+}, \\
\mathrm{Pb}^{2+},(\mathrm{Me})_{3} \mathrm{~Pb}^{+} \text {and }(\mathrm{Et})_{3} \mathrm{~Pb}^{+}\end{array}$ & Sodium pentanesulfonate & $\mathrm{C} 18$ & $20 \% \mathrm{ACN}$ & {$[33]$} \\
\hline $\begin{array}{l}\text { Arsenite, } \mathrm{DMA}, \mathrm{MMA}, \\
\text { arsenate, } p \text {-ASA }\end{array}$ & $\begin{array}{l}\text { Tetrabutylammonium } \\
\text { hydroxide }\end{array}$ & $\mathrm{C} 18$ & $\begin{array}{l}0.1 \% \mathrm{TFA} \text { and } \\
5 \% \mathrm{MeOH}\end{array}$ & {$[19]$} \\
\hline $\begin{array}{l}\text { Arsenite, } \mathrm{DMA}, \mathrm{MMA}, \\
\text { arsenate, } p \text {-ASA and 4-OH }\end{array}$ & $\begin{array}{l}\text { Tetrabutylammonium } \\
\text { hydroxide }\end{array}$ & $\mathrm{C} 18$ & Water & {$[12]$} \\
\hline
\end{tabular}

Reversed phase C18 columns are indicated to carry out the separation of cobalamins [35]. IPRP micro-bore HPLC has been applied to perform the separation of various cationic species of $\mathrm{Hg}$ and $\mathrm{Pb}[33]$ as well as anionic species of As [12] and Se compounds [24, 28]. In contrast to normalbore LC-ICPMS, where the use of high organic solvent flow rates has a detrimental effect on the ICP stability, a C18 nanocolumn (150 mm x $75 \mu \mathrm{m}$ i.d.) was used obtaining $2-2.5$ times higher intensities 
with a mobile phase of 60-70\% acetonitrile than with pure aqueous solution [26]. A C18 microcolumn has also been used in a preliminary study to illustrate the potential of UPLC-ICPMS to contribute to biomarker discovery via the profiling of sulphur and phosphorus-containing endogenous metabolites in metabolomic studies [50]. Capillary columns coupled to ICPMS are usually reversed phase C18 columns, with the special characteristic of the small sample volume required (as low as $100 \mathrm{~nL}$ ), relevant in some applications in which the available sample volume is low such as forensics, biopsy samples or single cell analysis [21-22]. Schaumlöffel et al. [27] showed that C18 capillary HPLC could be coupled with ICPMS with sufficient sensitivity and significantly higher chromatographic resolution and peak capacity than any of the HPLC-ICPMS couplings ever reported. In general, capillary columns coupled with ICPMS have been used for phosphopeptide identification [45], selenocompounds speciation [21-22, 27] and $\mathrm{Cu}$ and $\mathrm{Zn}$-proteins speciation [41].

C8 columns are RP stationary phases that have less hydrophobic retention than $\mathrm{C} 18$ but comparable selectivity and they are suitable for the determination of small, water-soluble molecules and peptides. Micro-bore C8 columns have been coupled to ICPMS for the determination of cobalamins [43], cadmium bio-induced ligands [39], metallothioneins [40], mercury [35], lead [35] and selenium [20] species, also with the use of an ion pairing reagent in the mobile phase. This type of column has also been used for the analysis of cis-platin adducts with DNA nucleotides [51] and for the investigation of different metal-containing proteins [41]. Finally, C4 microcolumn has been suggested for the separation of highly hydrophobic proteins, like Sel P, due to its low hydrophobicity [24].

Additional chromatographic separation mechanisms

Ion exchange chromatography is one of the most useful chromatographic mechanisms for speciation analysis of environmental samples [52]. For example, an anion exchange column has been used for 
the separation of $\mathrm{Cr}$ (III) and $\mathrm{Cr}$ (VI) [3, 8, 31, 53], arsenic and selenium compounds [13-16, 18, 54] and metal complexes [52].

Multimode gel filtration columns combine separation mechanisms such as SEC, ion exchange and reversed phase partitioning. Gel filtration nano-columns operating at $2-5 \mu \mathrm{L} \mathrm{min}{ }^{-1}$ have several advantages over other columns for the speciation of biometals [21]: (i) they can be used for biological fluids (tissue supernatants, urine and blood plasma) without requirement for a prior sample treatment; (ii) elution is carried out with salty solutions (similar to physiological conditions) without any detrimental effect on ICPMS due to the low liquid flow rate employed; and, (iii) they can be used for a wide size range of biomacromolecules such as proteins and nucleic acids. This kind of stationary phases was first proposed by Ogra et. al. [21] for the separation of selenocompounds. Then, it has been used for biological applications such as metalloproteins separation [30] and copper speciation [42].

Affinity micro-bore columns coupled to ICPMS have been successfully used to carry out the interference-free determination of selenoproteins [23] in limited-size samples. In this study, the simultaneous determination of glutathione peroxidase (GPx), selenoprotein P (SelP) and selenoalbumin (SeAlb) in human serum has been carried out in the shortest analysis time ever reported. This type of small-bore column has also been used for a rapid and effective determination of SelP in human [55] and mouse [56] plasma.

Adsoption chromatography is rarely used in speciation analysis because the high polarity of the stationary phase and the highly non-polar character of the mobile phase can cause irreversible adsorption of species [5].

Multidimensional chromatography allows the separation of complex mixtures by using multiple columns with different stationary phases. These columns are coupled orthogonally, which means that fractions from the first column can be selectively transferred to other columns for additional separation, thus enabling separation of complex mixtures that cannot be separated using a single 
column. For example, the separation of hydrophilic Se-metabolites was accomplished by the combined used of hydrophilic interaction liquid chromatography (HILIC) and SEC [25].

\subsection{Interfaces}

The coupling of HPLC with ICP spectrometry is a relatively easy task. This is because of the compatibility between the mobile phase flow rates used in HPLC and the sample liquid flow rate commonly required when carrying out ICP analyses. When conventional chromatographic columns are adapted, both flow rates are on the order of $0.5-1.5 \mathrm{~mL} \mathrm{~min}^{-1}$. However, when small-bore columns are employed, the mobile phase flow rate is lowered down to several tens of microliters per minute. In order to obtain good sensitivities and, simultaneously, reduce the analyte dispersion, the interface must be modified [9]. The nebulizer and the spray chamber are one of the weakest points of the process because they contribute significantly to the band broadening. Furthermore, the mass of sample delivered to the plasma and, hence, the sensitivity depends on the quality of the aerosols produced by the nebulizer and on the spray chamber design. This section describes the different instrumental systems used as interface between LC and ICPMS.

\subsubsection{Micronebulizers/spray chambers}

The use of micronebulizers is the easiest way to match the low separation flow rates needed in microbore HPLC to that of ICP. These devices have the capability to efficiently produce a fine and uniform aerosol at low sample uptake rates (e.g., 10 - $100 \mu \mathrm{L} \mathrm{min}^{-1}$ ). The micronebulizers mainly used coupled to micro columns are the micro-concentric nebulizer (MCN) [57], high efficiency nebulizer (HEN) [11, 14, 19]; the oscillating capillary nebulizer (OCN) [58]; and the electrospray nebulizer [59]. Additional pneumatic nebulizers made of plastic materials (PFA) have also been employed for this purpose [18]. 
The MCN is a low-flow pneumatic concentric nebulizer designed to operate at flow rates between 50 and $200 \mu \mathrm{L} \mathrm{min}{ }^{-1}[39-40,50]$. The MCN has been used for the analysis of samples containing high concentrations of mineral acids, high levels of dissolved solids and many other types of dissolved and inorganic materials [13]. The installation is easy and no special requirement concerning the gas supply is needed. The MCN has been frequently used with small-bore columns coupled to ICPMS $[12,14,34,39-40,53,60]$, and it is commonly associated with a Scott-type doublepass spray chamber $[3,8,13,15,17,52]$, giving stable signals and a very low noise level. As organic solvents are often present in the mobile phase, $2-5 \%$ of oxygen has to be added to the nebulisation gas or in the spray chamber in order to facilitate the combustion of the residual solvent in the plasma thus avoiding soot deposit at the torch walls [24]. Due to the low liquid flow rate, the MCN can be coupled to a low-volume spray chamber $[45,60]$. In fact, conventional chambers have a large dead volume that degrades the resolution [9].

The HEN is another low-flow nebulizer used to efficiently couple HPLC with ICPMS at liquid uptake rates between 10 and $150 \mu \mathrm{L} \mathrm{min}^{-1}$ [9]. For example, this nebulizer was used for the speciation of five arsenic species, providing excellent detection limits and a reduction in solvent waste compared to conventional nebulizers [19]. This nebulizer has a dead volume (about $25 \mu \mathrm{L}$ ) much lower than that of a typical micro-bore column (roughly $200 \mu \mathrm{L}$ ) what that makes the off-column broadening to be negligible [18].

The OCN consists of two concentric fused silica capillary tubes, mounted concentrically with compression fittings. The OCN has been used with both small- and normal-LC-ICPMS interfaces because of its low dead volume and because it operates stably over an exceptionally wide range of liquid flow rates, from $1 \mu \mathrm{L} \mathrm{min}{ }^{-1}$ to $2 \mathrm{~mL} \mathrm{~min}^{-1}$. It is normally used with a single pass spray chamber. The OCN together with a micro-bore column operating at $50 \mu \mathrm{L} \mathrm{min}^{-1}$ results in an increase in the sensitivity in terms of peak height by one order of magnitude with respect to a traditional column (4.6 $\mathrm{mm}$ i.d.) operated at $0.4 \mathrm{~mL} \mathrm{~min}^{-1}$. This fact can be explained by considering a combination of higher analyte transport efficiency and improved plasma ionization conditions. No drain tube was necessary 
and it was possible to introduce $100 \%$ methanol for at least $2 \mathrm{~h}$ at flow rates lower than $50 \mu \mathrm{L} \mathrm{min}{ }^{-1}$ [58].

The electrospray nebulizer is based on the process whereby the aerosol is formed by the application of a strong electric field. It operates effectively at extremely low flow rates $(\leq 1-30 \mu \mathrm{L}$ $\min ^{-1}$ ). Using the electrospray interface it was possible to introduce $100 \%$ methanol into the plasma at up to $5 \mu \mathrm{L} \mathrm{min}{ }^{-1}$. However when this situation was maintained for a long time, the system showed significant carbon build-up on the cones. An electrospray nebulisation interface with a capillary liquid chromatography column has been successfully developed and it might be a good alternative for trace organometallic analysis, providing low detection limits, wide linear range and limited peak broadening [59].

As already anticipated, the spray chamber design and inner volume are very important to minimize the peak dispersion. Thus, Schaumlöffel et al. [61] designed a total consumption micronebulizer with a single-pass low-dead-volume spray chamber for selenopeptide mapping. This assembly showed significantly higher chromatographic resolution and detection sensitivity than any of the reported HPLC-ICPMS couplings [27]. This sample introduction system was also used for the speciation of selenocompounds with capillary HPLC [21-22]. The use of low-dead-volume singlepass spray chamber coupled with a designed nanoflow nebulizer [26] allowed the generation of a fine and stable aerosol at nanoliter-per-minute flow rates.

\subsubsection{Direct injection nebulizers}

The aforementioned interfaces have associated several problems: (i) the analyte transport efficiency is low (i.e., typically on the order of $2-20 \%$ ); (ii) a waste is generated and (iii) memory effects may cause peak overlapping because of the band broadening. Analyte losses are mainly associated with the generation of large droplets by the nebulizer and their subsequent removal from the aerosol in the spray chamber. Finally, especially if organic mobile phases are used, carbon deposits at either the ICPMS sampler cone or the injection torch can be observed. The so-called Direct Injection Nebulizer 
(DIN) does not use any spray chamber prior to the plasma [62]. The DIN tip [63-64] is located at a few millimetres below the plasma base, which promotes the use of micro-bore HPLC columns because all the column effluent is introduced into the plasma [30]. Therefore, they offer a $100 \%$ analyte transport efficiency, low dead volume, improved precision, minimum peak broadening and enhanced sensitivity $[33,35]$.

The DIN operates at liquid flow rates from 30 to $120 \mu \mathrm{L} \mathrm{min}{ }^{-1}$, it has an extremely low dead volume $(<2 \mu \mathrm{L})$ and the sample wash-out is fast, leading to minimal memory effects $[31,35,38,43]$. The main problems of this device are that it is very expensive, fragile and it is difficult to use [43]. Moreover some authors have noted that because of the high solvent load, local plasma cooling is produced $[15,58]$. The use of these low-flow rate nebulizers as a micro-bore HPLC-ICPMS hyphenation has been described in several papers $[20,24,28]$. These works showed that mobile phases with high concentrations of organic solvents could be introduced into the plasma with DIN although the signal intensity is influenced by variations in the organic solvent concentration. Chassaigne et al. [65] described the use of a DIN with mobile phases up to 50\% methanol for the analysis of cobalamins and metallothioneins. Unlike conventional nebulizers, the DIN coupled to micro-bore columns for $\mathrm{Cr}$ speciation provides a constant background and improves limits of detection by about 20 times compared with a conventional column [31]. Similar results were found for $\mathrm{Pb}$ and $\mathrm{Hg}$ speciation [33]. A DIN also shows a good performance to hyphenate UPLC with ICPMS [28]. When using DIN with small-bore columns, the addition of excess oxygen to the aerosol to prevent clogging was not necessary because of the low flow rate [30]. However, attention must be paid when choosing an eluent because the thin capillary of the DIN can be clogged very easily, for instance with samples containing high contents of dissolved salts [30-31, 33].

Direct Injection High Efficiency Nebulizer (DIHEN) appeared with the idea that (1) the HENspray chamber combination offers similar detection limits at solution uptake rates of less than $100 \mu \mathrm{L}$ $\min ^{-1}$ to those of conventional pneumatic nebulizers at $1-2 \mathrm{~mL} \mathrm{~min}^{-1}$ [9] and (2) the primary aerosols produced by the HEN exhibit droplet size distributions smaller and narrower than those reported for 
the DIN [66]. The DIHEN was constructed to combine the simplicity, low cost, and aerosol characteristics of the HEN with the well-documented advantages of the DIN. Therefore, this nebulizer has been used in conjunction with micro-bore HPLC [10, 35, 47]. Acon et al. [35] reduced the dead volume of the DIHEN (from 60 to $13 \mu \mathrm{l}$ ) by inserting a Teflon tubing. In this way, the peak broadening attributed to the DIHEN was $4 \%$ of the total peak width (i.e., 3 seconds). In other words, the main source of peak dispersion was the column. Another interesting finding was that, at low liquid flow rates, the plasma remained stable and no carbon deposits were found when organically modified mobile phases were used. Very low limits of detection were obtained for the determination of three naturally occurring cobalamin species and five organolead and organomercury species. A modified DIHEN was used for microLC-ICPMS by inserting an additional internal capillary and whereas it was slightly less sensitive than the original one, its signal stability and resolution were superior due to its extremely small dead volume [47]. Absolute detection limits $1-2$ orders of magnitude better than those obtained with conventional nebulizers were found for DIHEN, likely due to the complete nebulization of sample into the plasma [9].

A comparison study demonstrated that the nebulizer-spray chamber assemblies with larger dead volumes detrimentally affected the shape of the resulting peaks, generating band broadening and thus degrading the separation efficiency [14-15]. Figure 1 shows the separation of four arsenic species using a conventional cross-flow nebulizer and a MCN coupled with a Scott spray chamber and DIN [15]. It can be seen that DIN provided higher sensitivities and sharper peaks than the other systems due to the higher sample introduction efficiency and lower dead volume, respectively. In another study, a comparison of HEN and PFA nebulizers resulted in higher ICPMS sensitivities for the former one while no differences were observed in limits of detection and chromatographic resolution [18]. The performance of different nebulizers as the interface between LC and ICPMS were also compared by Castillo et al. [34] and Stenfánka et al. [10], with similar conclusions. 


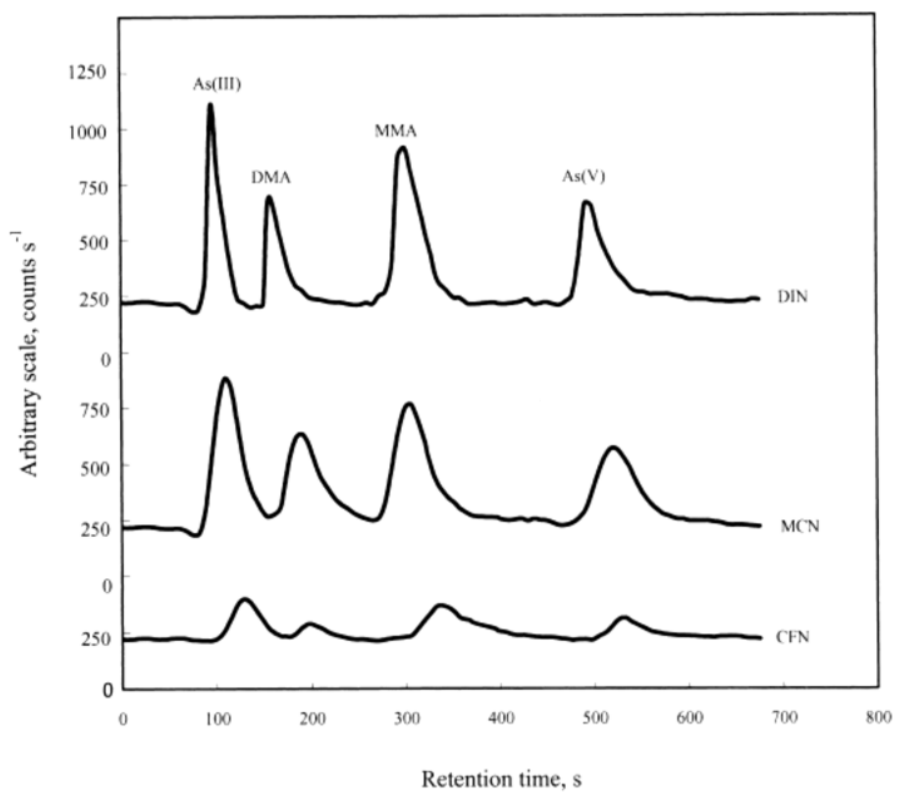

Fig. 1. The chromatograms obtained with use of different nebulizers as interface for the hyphenation of chromatographic separation and ICPMS. From ref. [15]

\subsubsection{Additional systems}

Some attempts to design other interfaces for HPLC-ICPMS coupling at low liquid flow rates were aimed at reducing the plasma solvent load. For example, a membrane desolvation system (MD) was suggested for the speciation of selenium by gradient elution. The principle of MD is based on the passive diffusion of solvent vapour through a tubular micro-porous PTFE membrane. In this case, the organic solvent contained in the mobile phase is removed and it does not reach the plasma. However, volatile species, such as some selenium compounds are lost in the membrane [24]. The claimed explanation is the transformation of, for instance, selenious acid in selenium dioxide through dehydration at the high working temperature. Additional volatile compounds (e.g., monomethyl selenic acid) can also be removed by diffusion through the membrane pores after their thermal degradation. Surprisingly, species such as trimethylselenonium can be efficiently determined through this means [24].

An additional desolvation system is based on the use of a heated cyclonic spray chamber followed by a multiple condenser (APEX Q). The system has been employed to interface affinity 
microHPLC to ICP-sector field (SF)MS. The achieved sensitivity was more than one order of magnitude higher than that found for a conventional double pass Scott-type spray chamber $\left(2{ }^{\circ} \mathrm{C}\right)$ for the determination of selenoproteins [23].

A second strategy was to optimize the interface for working at extremely low liquid flow rates. For example, a sheathless interface for capillary HPLC-ICPMS was employed at flow rates of 3-7 $\mu \mathrm{L}$ $\min ^{-1}$ [26]. This range could be extended down to $0.5 \mu \mathrm{L} \mathrm{min}{ }^{-1}$, but it resulted in increased signal instability [27, 46]. Similarly, Pröfrock et al. [46] tested a modified capillary electrophoresis nebulizer and a specially designed 4-mL spray chamber for nanoHPLC-ICPMS coupling at $0.5 \mu \mathrm{L} \mathrm{min}{ }^{-1}$. However, this attempt was unsuccessful because it resulted in a loss of chromatographic resolution and sensitivity. Further improvement to reduce dead volume is hence necessary in order to take advantage of the direct hyphenation of nanoLC and ICPMS.

Finally, the use of UV illumination/nano- $\mathrm{TiO}_{2}$ photocatalytic system and an effective and rapid pre-reduction process between the $\mu$ HPLC system and the Hydride Generation-ICPMS has been used to convert all the arsenic species into As (V) and later to As (III). In this way, an improvement in the analytical sensitivity and the determination of non-hydride-forming arsenic compounds was obtained [16].

\subsection{Effect of the mobile phase on ICPMS signal}

In order to successfully carry out speciation analysis by HPLC-ICPMS, it is necessary to use a mobile phase that is compatible with the ICPMS system, ideally plain water. However, most of separations, especially in RP chromatography, involve the use of organic solvents. Sometimes (e.g. for arsenic), low concentrations of methanol (e.g. 1-2\%) are added to the mobile phase to enhance the ionization efficiency of the plasma source.

It is well known that ICP shows a low tolerance against organic solvents, due to (i) unsatisfactory long-term stability caused by the formation of carbon deposits onto the torch, injector 
or interface cones [10]; (ii) changes in the aerosol generation and transport efficiency and (iii) changes in the ionization processes in the plasma. These phenomena are mainly due to the lower average drop size of the aerosol generated from organic solutions and to their higher evaporation rate, thus leading to high solvent load, cooling of the plasma and reduced ionization efficiency [10, 24, 67]. Also aqueous mobile phases are not completely problem-free. For example, the use of phosphate buffer as the mobile phase may cause salt depositions on the interface cones, thus affecting long-term stability.

The use of small-bore LC columns [44] along with a suitable interface between HPLC and ICPMS provides an excellent solution to the problems caused by organic or saline mobile phases, because of the reduced mobile phase mass to be transported to the plasma. For example, the use of a microconcentric nebulizer in combination with a MD [24] allowed the introduction of concentrations of methanol up to $90 \%$ without observing plasma instability or formation of carbon deposits on the cones, thus obtaining constant ICPMS signal for selenium, irrespective of the methanol concentration. On the other hand, other authors [68] reported significant effects on the ICPMS signal by changing the concentration of organic solvents during the gradient elution.

\section{Analytical performances}

\subsection{Retention times, resolution and efficiency.}

Retention times can be shortened by increasing the flow rate or reducing the column length, although these solutions will result in poor resolution [28]. The reduction in particle size $(1.7 \mu \mathrm{m})$ and the use of high pressures (UPLC and UHPLC) can also reduce the retention times, along with an increase of peak height and a decrease in the peak width [28, 69]. However, there is no obvious evidence of the reduction in retention times directly associated with the use of small-bore columns, due to the fact that both the column length and the liquid flow rate are reduced. Moreover, retention times in small- 
bore columns are affected by several factors like in normal bore columns, including the mobile phase composition [32-34, 37, 51], temperature [20], interface design [14, 47] and sample composition [70].

Concerning the chromatographic resolution, the major advantage claimed for small-bore columns comes from the decrease in the analyte transversal diffusion due to the reduced inner diameter of the column, with the consequent reduction of the peak width [9]. However, this is compensated by the lower liquid flow rate usually applied, as well as by the reduction of the number of theoretical plates due to the shortening of the column [10]. On the other hand, the resolution can be enhanced by an increase in the column length, although it causes an increase in the analysis time $[35,71]$. Table 3 reports the separation and detection parameters obtained with conventional and small-bore columns for four selenium compounds [21]. It can be confirmed that the observed plate number is lower when using small-bore columns, likely due to lower column length and liquid flow rate. However the resolution for the separation of the first two compounds was higher for the smallbore columns. If the theoretical plate is calculated with a 100x $2.1 \mathrm{~mm}$ chromatographic column but at different liquid flow rates (from 60 to $200 \mu \mathrm{L} \mathrm{min}^{-1}$ ) the result is an increase in the theoretical plate number with the decrease in liquid flow rate [18].

Table 3. Separation and detection parameters obtained with conventional and small-bore columns for four different selenium compounds (taken from ref. [21]).

\begin{tabular}{|c|c|c|c|c|c|c|c|c|c|}
\hline $\begin{array}{l}\text { Dimensions } \\
\text { Flow rate }\end{array}$ & \multicolumn{3}{|c|}{$\begin{array}{l}300 \times 7.6 \mathrm{~mm}^{-} \\
500 \mu \mathrm{Lin}^{-1}\end{array}$} & \multicolumn{3}{|c|}{$\begin{array}{c}150 \times 0.5 \mathrm{~mm} \\
2 \mu \mathrm{L} \mathrm{m^{-1 }} \\
\end{array}$} & \multicolumn{3}{|c|}{$\begin{array}{c}250 \times 0.8 \mathrm{~mm} \\
5.5 \mu \mathrm{L} \mathrm{min}^{-1}\end{array}$} \\
\hline \multirow{2}{*}{$\begin{array}{l}\text { Injection } \\
\text { volume }\end{array}$} & \multicolumn{3}{|c|}{$20 \mu \mathrm{L}$} & \multicolumn{3}{|c|}{$100 \mathrm{~nL}$} & \multicolumn{3}{|c|}{$100 \mathrm{~nL}$} \\
\hline & $\mathrm{N}^{\mathrm{a}}$ & $\mathrm{S} / \mathrm{N}^{\mathrm{b}}$ & $\mathrm{R}^{\mathrm{c}}$ & $\mathrm{N}$ & $\mathrm{S} / \mathrm{N}$ & $\mathrm{R}$ & $\mathrm{N}$ & $\mathrm{S} / \mathrm{N}$ & $\mathrm{R}$ \\
\hline gGluMeSeCys & 11341 & 964 & 266 & 5711 & 1443 & 20 & 6165 & 400 & ? \\
\hline MeSeCys & 11355 & 1165 & 2.00 & 6209 & 1627 & 5.22 & 7671 & 459 & 3.12 \\
\hline MeSeGalNAc & 12882 & 91.2 & 306 & 5785 & 133.8 & 188 & 4967 & 92.1 & 20 \\
\hline TMSe & 17951 & 51.6 & & 8084 & 90.4 & & 7992 & 60.4 & \\
\hline
\end{tabular}

${ }^{\mathrm{a}}$ Observed plate number. ${ }^{\mathrm{b} S i g n a l-t o-n o i s e}$ ratio. ${ }^{\mathrm{c}}$ Resolution between two peaks of the major selenocompounds 
Besides column dimensions, the resolution can be modified by different variables such as the concentration of organic solvent in the mobile phase and the interface system. For example, a decrease in the overall resolution was reported by increasing the amount of methanol [11]. On the other hand, the optimization of the gradient conditions resulted in good peak resolution and shape for the analysis of four naturally occurring cobalamines and cobinamide [43]. Concerning the interface, it was observed that DIN and MCN yielded a higher chromatographic resolution in arsenic speciation than that obtained using a conventional nebulizer system [15].

The chromatographic efficiency can be improved by the use of columns with smaller particle size than the conventional ones. In fact, according to the van Deemter equation, the theoretical plate height is reduced when the particle size is decreased [28, 69, 72]. Moreover, beyond the optimum velocity the theoretical plate height varies only slightly with increasing the linear velocity, thereby allowing the use of high flow rates without significantly affecting the resolution. However, special systems (named UHPLC or UPLC) are needed when reducing the particle size to maintain the higher backpressure required. Bendahl et al. [72] were the first who coupled UPLC with ICPMS in the speciation field for the analysis of bromine-containing preservatives using a micro-bore column packed with $1.7 \mu \mathrm{m}$ particle.

\subsection{Sensitivity and limits of detection.}

As the micro-bore columns operate at lower flow rates than conventional ones, the relative peak concentration is higher for the former and better sensitivities are hence expected. Furthermore, the analyte transport efficiency grows as the liquid flow rate drops. As a constant sample volume is injected into the system, the net mass of analyte delivered to the plasma is lower at high than at low liquid flow rates. This is clearly shown in Table 3, where a significant increase in the absolute sensitivity may be observed for the small-bore columns considering the 200 -fold reduction in the injection volume. 
Sensitivity also depends on other factors, mainly the interface employed. For example, Bendahl et al. [24] reported a 50\% lower sensitivity using the MCN/cyclonic spray chamber system compared to $\mathrm{MCN} / \mathrm{membrane}$ desolvator and DIN systems for the speciation of selenium compounds. In the arsenic speciation field, Todolí and Grotti [18] demonstrated that HEN nebulizer provided a 50\% higher sensitivity than PFA, irrespectively of the arsenosugars considered. However, the improvement in sensitivity by HEN over the PFA decreased with lowering the flow rate (about $30 \%$ at $100 \mu \mathrm{L} \mathrm{min}^{-1}$ and about $10-20 \%$ at $60 \mu \mathrm{L} \mathrm{min}^{-1}$ ). These results were explained taking into account the higher solvent evaporation inside the spray chamber when working at low liquid flow rates.

As regards limits of detection, it has been shown that small-bore columns generally provide figures comparable to normal-bore columns, despite the former ones work at much lower liquid flow rates. For instance, Castillo et al. [14] demonstrated that detection limits as low as those obtained by conventional HPLC-ICPMS can be achieved for the speciation of arsenic and selenium compounds, provided that the HEN is used. Similarly, Bendahl et al. [72] analyzed bromine-containing preservatives by UPLC-ICPMS at $50 \mu \mathrm{L} \mathrm{min}^{-1}$, reporting detection limits comparable with those previously obtained by conventional HPLC-ICPMS. The detection limits can be further improved by increasing injection volumes [32, 41], although this leads to degradation in the chromatographic separation.

\subsection{Column recovery}

Speciation analysis with HPLC-ICPMS usually comprises three steps: extraction, separation and selective detection of species, and reliable quantitative results would require the knowledge of mass balance on the distribution of the element during each step. Surprisingly, not all studies clearly report the relevant data and it is unclear if and where losses occur [73]. Extraction efficiency is a major concern also in the speciation analysis by small-bore HPLC-ICPMS and it is merely related to the sample preparation procedure. Column recovery may be defined as the ratio between the sum of the 
eluted species and the total elemental concentration in the injected solution. For example, Jitaru et. al. [23] determined the column recovery for the determination of selenoproteins in human serum by comparison of the total AF-HPLC peak area $(\mathrm{GPx}+\mathrm{SelP}+\mathrm{SeAlb})$ with that of the peak obtained by the analysis of the same amount of serum in flow injection mode (no column used). A recovery of $\sim 100 \%$ was obtained for the HEP column, whereas only $\sim 80 \%$ of selenoproteins was recovered from the BLUE column, likely due to the low recovery of SelP. The mass balance between the sum of the quantified species and the total concentration in the sample was also evaluated by Chen and coworkers [36] for mercury speciation in seawater and by Vanhaecke and co-workers [3] for chromium speciation in industrial process solutions, both reporting quantitative column recoveries. 


\section{Applications}

The main applications of narrow-bore HPLC coupled to ICPMS in the field of arsenic speciation analysis are summarized in Table 4. A narrow-bore reversed-phase HPLC column with ion-pairing was used for the first time by Pergantis et al [11] to determine phenylarsonic compounds used as animal feed additives in environmental (water and soil extracts) and biological (urine) reference samples. The developed method provided a good separation of the target analytes from the naturally occurring arsenic compounds, with low detection limits, small sample size $(<1 \mu \mathrm{l})$ and reduced solvent consumption (40 $\mu \mathrm{L} \mathrm{min}^{-1}$ ). Later, a similar chromatographic system was used by Wangkarn and Pergantis [12] to accomplish a fast $(<3 \mathrm{~min})$ determination of $\mathrm{As}^{\mathrm{III}}, \mathrm{As}^{\mathrm{V}}, \mathrm{MA}$ and DMA in wine samples and of arsenosugars in kelp powder extracts. However, a wider column $(2.1 \mathrm{~mm}$ vs $1 \mathrm{~mm}$ i.d.) and much higher mobile phase flow rate $\left(700 \mu \mathrm{L} \mathrm{min}^{-1}\right.$ vs $\left.40 \mu \mathrm{L} \mathrm{min}^{-1}\right)$ were used in this occasion. Woller et al. [13] reported the simultaneous speciation of redox species of arsenic ( $\left.\mathrm{As}^{\mathrm{III}}, \mathrm{As}^{\mathrm{V}}\right)$ and selenium $\left(\mathrm{Se}^{\mathrm{IV}}, \mathrm{Se}^{\mathrm{VI}}\right)$ in natural water samples and polluted soil leachings, using an anion-exchange micro-bore column. The chromatographic run time was about $4 \mathrm{~min}$ and the instrumental limits of detection at the ppb-level. However, possible interconversion of $\mathrm{As}^{\mathrm{V}}$ to $\mathrm{As}^{\mathrm{III}}$ and $\mathrm{Se}^{\mathrm{VI}}$ to $\mathrm{Se}^{\mathrm{IV}}$ in the real samples was highlighted. Similarly, Castillo et al. [14] achieved the simultaneous separation of arsenic ( $\mathrm{As}^{\mathrm{III}}, \mathrm{As}^{\mathrm{V}}, \mathrm{MA}$ and $\mathrm{DMA}$ ) and selenium $\left(\mathrm{Se}^{\mathrm{IV}}, \mathrm{Se}^{\mathrm{VI}}\right)$ species by anion-exchange chromatography, using a PRP-X100 1mm-ID column along with mobile phases based on a mixture of $\mathrm{NH}_{4} \mathrm{H}_{2} \mathrm{PO}_{4}$ and $\mathrm{NH}_{4} \mathrm{NO}_{3}$. Detection limits were in the range of $0.03-0.04 \mu \mathrm{g} / \mathrm{l}$ for arsenic species and $0.35 \mu \mathrm{g} / 1$ for selenium species. The method was applied to different spiked environmental water samples, showing good accuracy and repeatability, although the analysis of the high salinity samples required the mathematical correction of ArCl-interference on MMA determination. Sun et al. [15-16] reported the determination of $\mathrm{As}^{\mathrm{III}}, \mathrm{As}^{\mathrm{V}}, \mathrm{MA}$ and DMA in urine samples by anion-exchange narrowbore HPLC, using pneumatic nebulisation [15] or UV photooxidation/Hydride Generation [16] as the interface between the chromatographic system and ICPMS. The achieved detection limits were in the 
0.2-0.4 $\mu \mathrm{g} / \mathrm{l}$ range. Narrow-bore ion chromatography coupled to ICP-SFMS was applied by Ammann [17] to determine $A s^{\mathrm{III}}, \mathrm{As}^{\mathrm{V}}, \mathrm{MA}, \mathrm{DMA}$ and $\mathrm{AB}$ in groundwater samples. The use of $\mathrm{NH}_{4} \mathrm{NO}_{3}$ as the mobile phase allowed an easy selection of the $\mathrm{pH}$ to enhance the selectivity without compromising the eluent ionic strength and the 50-100 sample dilution drastically reduced the matrix influences on the separation. Possible reduction of $\mathrm{As}^{\mathrm{V}}$ to $\mathrm{As}{ }^{\mathrm{III}}$ due to column deposits during the gradient run was eliminated by an appropriate $\mathrm{PO}_{4}$-excess in the injected sample, thus preventing artefacts in $\mathrm{As}^{\mathrm{III}} / \mathrm{As}^{\mathrm{V}}$ ratios. Finally, Todolí and Grotti [18] reported the fast determination of arsenosugars in algal extracts by narrow bore HPLC-ICPMS in conjunction with a low sample consumption system. Accurate and precise determination of the major arsenosugars in algae was obtained, with comparable sensitivity as the conventional system, but with strongly reduced analytical times, lower sample and mobile phase volumes and minor matrix loading into the ICP and interface regions of the ICP mass spectrometer.

Selected applications of narrow-bore HPLC coupled to ICPMS for speciation analysis of selenium are compiled in Table 5. Gammerlgaard et al. [20] reported the determination of selenium metabolites in urine samples by ion-paring chromatography with perfluorinated carboxylic acids and ICPMS detection. The separation was performed on a micro-bore C8 column, connected to the ICPMS via a laboratory-made direct injection nebuliser, which allowed the introduction of high methanol concentrations at the flow rate of $50 \mu \mathrm{L} \mathrm{min}^{-1}$. The detection limits in urine ranged between 0.8 and $1.7 \mu \mathrm{g} / \mathrm{l}$. Urinary selenium metabolites were also determined by Ogra and Suzuki [21] using capillary HPLC coupled to ICPMS through a total consumption sample introduction system. Two major selenometabolites (1- $\beta$-methylseleno- $N$-acetyl-D-galactosamine and TMSe) were successfully measured in the urine of a Se-toxicosis rat using a 0.5mm-ID gel-permeation column, with 50-75\%higher signal-to-noise ratios, 30\%-shorter analytical time and 200-fold lower sample consumption compared to conventional HPLC. Similar improvements were also obtained for two major selenocompounds ( $\gamma$-glutamyl-Se-methylselenocysteine and MeSeCys) in selenized garlic. RuizEncinar and co-workers [22] reported a method for the accurate determination of SeMet and SeCys 
in human serum using reverse-phase capillary HPLC-ICPMS with species-specific isotope dilution calibration. The serum sample was enzymatically digested and the selenoamino acid fraction was isolated by SEC, followed by the separation of SeMet and the carboxymethylated SeCys on a 0.3mmID C18 column. The interference-free determination of ${ }^{77} \mathrm{Se}$ and ${ }^{80} \mathrm{Se}$ was achieved by using the reaction cell pressurized with hydrogen. The method detection limit was below $0.5 \mathrm{ng} / \mathrm{g}$ for a 450 mg serum sample and the precision was better than 5\%. Jitaru et al. [23] reported the speciation analysis of selenoproteins in human serum using micro-bore affinity HPLC hyphenated to ICPSFMS. Simultaneous determination of GPx, Sel P and seleno-albumin in only $5 \mu 1$ of human serum was carried out in less than 7 minutes. Due to the use of high mass resolution, no correction equations or preliminary sample preparation steps for removing the $\mathrm{Cl}$ - and $\mathrm{Br}$-based interferences were necessary. In order to compensate for the loss in sensitivity due to the high-resolution mode and the very low amount of sample taken for analysis, a high-efficiency sample nebulisation/desolvation system was employed. The analysis of human Sel P was also performed by Bendhal et al. [24] using micro-bore reversed phase chromatography with methanol gradient elution. By the application of a micronebulizer in association with a membrane desolvation unit, increasing amounts of methanol (up to $90 \%$ ) were introduced into the ICPMS instrument without any significant effect on the analytical signal, thereby allowing the quantification of human Sel P isoforms on the basis of an internal TMSe standard. A similar chromatographic system was applied for the analysis of the water soluble fraction of ${ }^{77} \mathrm{Se}$-enriched yeast and more than 30 selenium compounds were separated using a linear gradient from $5 \%$ to $95 \%$ methanol. Unfortunately, none of those peaks was identified. Far and co-workers [25] achieved the separation of a number of hydrophilic selenium compounds in selenium-rich yeast extracts using micro-bore HILIC-ICPMS after fractionation by SEC. Elution was carried out isocratically with ammonium acetate buffer in $80 \%$ acetonitrile and a total consumption sample introduction system was used as the interface to ICPMS. Out of 15 peaks observed with the Sespecific ICPMS detection, 12 were identified by ESI Q-TOF MS/MS. Finally, downscaling of HPLC in the selenium speciation field is exemplified by the paper by Giusti et al. [26] that reported the 
interfacing of nanoHPLC with ICPMS, through a nanoflow nebulizer coupled to a low-volume evaporation chamber and its application to the analysis of a tryptic digest of SIP18 protein. The sample volume was only $11 \mathrm{nl}$ and the employed liquid flow rate, as low as $300 \mathrm{~nL} \mathrm{~min}^{-1}$, enabled the stable introduction into the ICPMS of aqueous mobile phases containing up to $95 \%$ acetonitrile. The achieved absolute detection limit was $25 \mathrm{fg}$, which allowed the detection of low-abundant selenopeptides at the femtomole level. Identification of selenopeptides was carried out by parallel nanoHPLC-ESIMS.

Another topic of great interest in the bioinorganic speciation analysis field pertains to the characterization of heavy metals complexes with bioligands, mainly cystein-rich polypeptides termed metallothionein (MTs). Most relevant applications of narrow-bore HPLC coupled to ICPMS for the analysis of Cd-, $\mathrm{Cu}$ - and Zn-MTs are summarized in Table 6. Chassaigne and Lobinski [38] discussed the speciation of MT-bound cadmium by reversed-phase HPLC with ion-spray and ICPMS detection. A micro-bore C8 column with a gradient of up to $50 \%$ methanol in acetate buffer was successfully applied to separate the Cd-MT isoforms in the rabbit liver MT-2. The coupling of HPLC with ICPMS was realised by a direct injection nebulizer, allowing the specific detection of cadmium down to the $10 \mu \mathrm{g} / 1$ level. Similarly, Polec et al. [39-40] investigated the identification of metal complexes with MTs in rat liver and kidney using parallel HPLC-ICPMS and HPLC-ESIMS. The mixture of MT complexes was isolated from the tissues by SEC and further preconcentrated by lyophilization and desalting. The resulting sample was finally analysed by micro-bore reversed-phase HPLC coupled to ICPMS or ESIMS. The analytical approach allowed the detection of two major MT isoforms in liver and one MT isoform in kidney. Montes-Bayon et al. [41] reported the application of capillary HPLC coupled to collision cell ICPMS for the determination of $\mathrm{Cu}$ - and $\mathrm{Zn}$-proteins extracted from red blood cells of seal samples. The selected column was a $0.3 \mathrm{~mm}-\mathrm{ID}$ C8 and the separation conditions involved a gradient up to $80 \%$ methanol in $10 \mathrm{mM}$ ammonium acetate buffer. A new total consumption sample introduction system permitted to work at very low flow rate $\left(3 \mu \mathrm{L} \mathrm{min}{ }^{-1}\right)$ with high methanol content, while maintaining the sensitivity throughout the chromatographic run. In 
order to investigate the $\mathrm{Cu}$ metabolism in mutant mouse neonates, Miyayama and co-workers [42] analysed micro-amounts of tissue supernatants by narrow-bore HPLC coupled with ICPMS. Cu species were separated on a gel- permeation $2 \mathrm{~mm}$-ID column using Tris- $\mathrm{HCl}$ as the mobile phase and the relationship between the amount of $\mathrm{Cu}$ in the MT-bound form and MT mRNA expression was evaluated and discussed.

Determination of metal species showing various degree of toxicity is a major issue in the environmental and toxicological field. Representative applications of narrow-bore HPLC-ICPMS for the speciation of $\mathrm{Cr}, \mathrm{Hg}$ and $\mathrm{Pb}$ are presented in Table 7. Zoorob et al. [31] achieved the separation of $\mathrm{Cr}^{\mathrm{III}}$ (pre-complexed with 2,6-pyridinedicarboxylic acid) and $\mathrm{Cr}^{\mathrm{VI}}$ on a micro-bore $\mathrm{AS} 11$ column, using $7 \mathrm{mM}$ 2,6-pyridinecarboxylic acid and $0.6 \mathrm{mM}$ lithium hydroxide at $\mathrm{pH} 7.7$ as the mobile phase. A direct injection nebulizer was designed and used to introduce the eluent into the mass spectrometer at $150 \mu \mathrm{L} \min ^{-1}$. The method was applied to the analysis of the certified urine SRM 2670, obtaining accurate results for $\mathrm{Cr}^{\mathrm{III}}$ at $\mathrm{m} / \mathrm{z} 52$. On the other hand, at $\mathrm{m} / \mathrm{z} 53$ the $\mathrm{Cr}^{\mathrm{III}}$ peak was overlapped by a large peak due to Cl-based interferences. Moreover, the analytical time was quite high (20 min). Vanhaecke and co-workers [3] reported the fast (5 min) determination of $\mathrm{Cr}^{\mathrm{III}}$ and $\mathrm{Cr}^{\mathrm{VI}}$ in industrial process solutions by micro-bore anion exchange HPLC coupled to ICP-SFMS. As the mobile phase consisted of 60mM $\mathrm{HNO}_{3}$, matrix effects often encountered in HPLC-ICPMS (e.g. reduction of ion transmission due to clogging of the sampler cone) were minimized. The spectral interferences due to co-eluting $\mathrm{C}$ - and Cl-containing species were eliminated by the application of medium mass resolution $(\mathrm{R}=3000)$, although this mode led to a 15 -fold reduction in transmission efficiency (sensitivity). Nevertheless, for both species involved, sub- $\mu \mathrm{g} / \mathrm{l}$ limits of detection were achieved. Speciation of mercury and lead compounds by narrow-bore HPLC-ICPMS was investigated by Shum et al. [33]. Various cationic species of mercury $\left(\mathrm{Hg}^{2+}, \mathrm{MeHg}^{+}, \mathrm{EtHg}^{+}, \mathrm{PhHg}^{+}\right)$and $\mathrm{lead}\left(\mathrm{Pb}^{2+}\right.$, $\left.(\mathrm{Et})_{3} \mathrm{~Pb}^{+},(\mathrm{Me})_{3} \mathrm{~Pb}^{+}\right)$were separated by IP-RP chromatography and determined in spiked urine samples, with limits of detection of $0.1 \mu \mathrm{g} / \mathrm{l}$ and $4-8 \mu \mathrm{g} / \mathrm{l}$ for $\mathrm{Pb}$ for $\mathrm{Hg}$ species, respectively. Finally, Castillo et al. [34] developed a method based on the microHPLC-ICPMS coupling for the 
determination of four mercury species in spiked environmental waters, including groundwater, depurated urban wastewater and seawater. Gradient elution using methanol and L-cysteine at $\mathrm{pH} 3.0$ allowed the chromatographic separation of all species in about $15 \mathrm{~min}$. Detection limits ranged from 8 to $32 \mathrm{ng} / \mathrm{l}$. However, low recovery for high saline samples was observed.

According to the enlargement of the speciation concept to the analysis of compounds of interest by monitoring an elemental tag, narrow-bore HPLC-ICPMS was also applied to identify and/or quantify other species than those previously reported. Representative examples are reported in Table 8. Wind et al. [45] described a method for phosphopeptide identification by capillary liquid chromatography interfaced alternatively to ICPMS ( ${ }^{31} \mathrm{P}$ detection) and ESIMS. The separation was performed on a $0.2 \mathrm{~mm}$-ID C18 column using acetonitrile gradient (up to $80 \%$ ) elution. The method was applied to the analysis of a complex mixture of synthetic phosphopeptides and to tryptic digests of three phosphoproteins, namely $\beta$-casein, activated MAP kinase and protein kinase A catalytic subunit. Similarly, Profrock and co-workers [46] coupled capillary- and nano-HPLC with collisioncell ICPMS for phosphorylation profiling of tryptic protein digests. Sar et al. [51] determined cisplatin adducts with DNA nucleotides using narrow-bore HPLC-ICPMS with elemental specific detection of ${ }^{31} \mathrm{P}$ and ${ }^{195} \mathrm{Pt}$. A 2-1mm-ID C8 column was used with a mobile phase containing $60 \mathrm{mM}$ ammonium acetate $(\mathrm{pH}=5.8)$ and $7.5 \%$ methanol, allowing an easy separation and detection of free nucleotides (by monitoring phosphorus) from the synthesized adduct (containing phosphorus and platinum in the same molecule). Structural characterization of adducts was accomplished by ESI-QTOF-MS. Chassaigne and Lobinski [43] reported the determination of cobalamins in pharmaceutical preparations by narrow-bore HPLC with ICPMS detection. Five cobalamins and cobinamide dicyanide were separated in 30 min on a 1mm-ID C8 column, using methanol linear gradient from 10 to $40 \%$ in $25 \mathrm{mM}$ ammonium acetate buffer ( $\mathrm{pH} 4$ ). Detection limits ranged from 10 to $50 \mu \mathrm{g} / 1$. Finally, Nowak and Seubert [70] accomplished the ultra-trace determination of bromate in drinking waters by means of micro ion chromatography coupled to ICPMS. The method employed a 2mm-ID column filled with a self-made high-capacity anion exchanger and elution with $\mathrm{NH}_{4} \mathrm{NO}_{3}$, enabling 
the direct analysis of almost every water sample without matrix elimination, at concentration levels ranging from 0.05 to $10 \mu \mathrm{g} / \mathrm{l}$. However, it was observed that retention behaviour of bromate as well as background levels were influenced by the sample composition.

Aqueous mobile phases have many advantages for ICPMS, but they have also many disadvantages as to the types of compound that can be separated in this way, Smith et. al. used a micro-bore column with a isotopically enriched methanol as the organic modifier with the advantages of low flows then the quantity of methanol that arrives to the plasma is reduced and the solvent consumption is also reduced [74].

Malavolta et al. [60] used a gradient anion exchange microcolumn coupled to a ICPMS though MicroMist nebulizer and a Cinnabar Cyclonic spray chamber for the speciation of different metals $\mathrm{Fe}, \mathrm{Cu}$ and $\mathrm{Se}$ in biological samples. They obtained the chromatograms in less than 10 min without waiting for column wash and regeneration after each run, with very limited amount of biological material. With this technique is possible the screening of changes of trace elements distribution in serum among individuals caused by various diseases or treatment or physiological changes. 
Table 4. Selected applications of small-bore HPLC coupled to ICPMS for speciation analysis of arsenic.

\begin{tabular}{|c|c|c|c|c|c|c|c|c|c|c|}
\hline Analytes $^{\mathrm{a}}$ & Sample & HPLC $^{b}$ & Interface & $\mathrm{ICPMS}^{\mathrm{c}}$ & $\begin{array}{l}\text { Flow rate } \\
\left(\mu \mathrm{L} \min ^{-1}\right)\end{array}$ & $\begin{array}{l}\text { Volume } \\
(\mu \mathrm{l})\end{array}$ & $\begin{array}{l}\text { Time } \\
\text { (min) }\end{array}$ & $\begin{array}{l}\mathrm{LOD}^{\mathrm{d}} \\
(\mu \mathrm{g} / \mathrm{l})\end{array}$ & Notes & Ref \\
\hline $\begin{array}{l}\mathrm{As}^{\mathrm{III}}, \mathrm{As}^{\mathrm{V}} \\
\mathrm{p}-\mathrm{ASA}, 4-\mathrm{OH}\end{array}$ & $\begin{array}{l}\text { Spiked water, } \\
\text { soil and urine } \\
\text { CRMs }\end{array}$ & $\begin{array}{l}\text { IP-RP }(\mathrm{C} 18150 \times 1 \mathrm{~mm} \text {, } \\
3 \mu \mathrm{m}) \\
0.5 \% \mathrm{MeOH}+5 \mathrm{mM} \\
\mathrm{TBAH}^{\mathrm{e}}(\mathrm{pH} 5.8)\end{array}$ & $\begin{array}{l}\text { Modified HEN+ } \\
\text { Scott-type spray } \\
\text { chamber [19] }\end{array}$ & Q & 40 & $0.5-1$ & 10 & $0.6-0.9$ & $\begin{array}{l}\text { Co-elution of } \mathrm{As}^{\mathrm{III}} \text { and } \\
\mathrm{AB} \text { in the urine sample }\end{array}$ & [11] \\
\hline $\begin{array}{l}\mathrm{As}^{\mathrm{III}}, \mathrm{As}^{\mathrm{V}} \\
\mathrm{MA}, \mathrm{DMA} \\
\text { Arsenosugars }\end{array}$ & $\begin{array}{l}\text { Wines and kelp } \\
\text { powder extract }\end{array}$ & $\begin{array}{l}\text { IP-RP }(\mathrm{C} 18150 \times 2.1 \\
\mathrm{mm}, 4 \mu \mathrm{m}) \\
5 \mathrm{mM} \text { TBAH }(\mathrm{pH} 6.2)\end{array}$ & $\begin{array}{l}\text { Micromist+ } \\
\text { impact bead } \\
\text { water-cooled } \\
\left(5^{\circ} \mathrm{C}\right) \text { spray } \\
\text { chamber }\end{array}$ & Q & 700 & 1 & 2.7 & $0.3-1.3$ & $\begin{array}{l}\text { 4-OH was used as the } \\
\text { internal standard for } \\
\text { wine analysis }\end{array}$ & [12] \\
\hline $\begin{array}{l}\mathrm{As}^{\mathrm{III}}, \mathrm{As}^{\mathrm{V}} \\
\mathrm{Se}^{\mathrm{IV}}, \mathrm{Se}^{\mathrm{VI}}\end{array}$ & $\begin{array}{l}\text { Spiked } \\
\text { groundwater; } \\
\text { polluted soil } \\
\text { leaching }\end{array}$ & $\begin{array}{l}\text { AE (ANX-1606As; } 100 \\
\text { x } 2 \mathrm{~mm}) \\
5 \mathrm{mM} \mathrm{CH}_{2}\left(\mathrm{COONH}_{4}\right)_{2} \\
(\mathrm{pH} 8.5)\end{array}$ & $\begin{array}{l}\text { MCN-100+ } \\
\text { Scott-type spray } \\
\text { chamber }\end{array}$ & Q & 100 & 10 & 4 & $\begin{array}{l}1(\mathrm{As}) \\
6(\mathrm{Se})\end{array}$ & $\begin{array}{l}\text { Possible } \\
\text { interconversion of } \\
\text { redox species }\end{array}$ & [13] \\
\hline
\end{tabular}

${ }^{\mathrm{a}} \mathrm{As}{ }^{\mathrm{III}}=$ arsenite $; \mathrm{As}^{\mathrm{V}}=$ arsenate; $p$-ASA = p-arsanilic acid ; 4-OH = 4-hydroxyphenylarsonic acid; $\mathrm{AB}=$ arsenobetaine; $\mathrm{MA}=$ methylarsonate; $\mathrm{DMA}=$ dimethylarsinate; Arsenosugars = dimethylarsinoylribosides; $\mathrm{Se}^{\mathrm{IV}}=$ selenite; $\mathrm{Se} \mathrm{VI}^{\mathrm{VI}}$ selenate.

${ }^{\mathrm{b}}$ HPLC system: AE = anion-exchange chromatography; RP = reverse-phase chromatography; IP-RP = ion-pairing reverse-phase chromatography; IC = ion chromatography.

${ }^{c}$ ICPMS instrument: $\mathrm{Q}=$ quadrupole; $\mathrm{SF}=$ sector field ( $\mathrm{LR}=$ low resolution, $\mathrm{MR}=$ medium resolution, $\mathrm{HR}=$ high resolution); $\mathrm{CRC}=$ collision/reaction cell.

${ }^{\mathrm{d}}$ LOD $=$ limit of detection. Values, unless otherwise stated, refer to instrumental LOD.

e $\mathrm{TBAH}=$ tetrabutylammonium hydroxide. 


\begin{tabular}{|c|c|c|c|c|c|c|c|c|c|c|}
\hline $\begin{array}{l}\mathrm{As}^{\mathrm{III}}, \mathrm{As}^{\mathrm{V}} \\
\mathrm{MA}, \mathrm{DMA} \\
\mathrm{Se}^{\mathrm{IV}}, \mathrm{Se}^{\mathrm{VI}}\end{array}$ & $\begin{array}{l}\text { Spiked surface } \\
\text { water; spiked } \\
\text { water treatment } \\
\text { plant }\end{array}$ & $\begin{array}{l}\mathrm{AE}(\mathrm{PRP}-\mathrm{X} 100 ; 150 \times 1 \\
\mathrm{mm}, 3 \mu \mathrm{m}) \\
\mathrm{NH}_{4} \mathrm{NO}_{3} / \mathrm{NH}_{4} \mathrm{H}_{2} \mathrm{PO}_{4} \\
\text { gradient (pH 8.3) }\end{array}$ & $\begin{array}{l}\text { HEN+ } \\
\text { Scott-type } \\
\text { cooled }\left(2^{\circ} \mathrm{C}\right) \\
\text { spray chamber }\end{array}$ & Q & 100 & 15 & 5 & $\begin{array}{c}0.03-0.04 \\
(\mathrm{As}) \\
0.35(\mathrm{Se})\end{array}$ & $\begin{array}{l}\text { Correction equation } \\
\text { needed for MA in high } \\
\text { salinity samples }\end{array}$ & [14] \\
\hline $\begin{array}{l}\mathrm{As}^{\mathrm{III}}, \mathrm{As}^{\mathrm{V}} \\
\text { MA, DMA }\end{array}$ & Urine CRMs & $\begin{array}{l}\text { AE (Nucleosil SB; } \\
150 x 1 \mathrm{~mm}, 5 \mu \mathrm{m}) \\
20 \mathrm{mM} \mathrm{NH}_{4} \mathrm{H}_{2} \mathrm{PO}_{4} / \\
\left(\mathrm{NH}_{4}\right)_{2} \mathrm{HPO}_{4}(\mathrm{pH} 5.25)\end{array}$ & $\begin{array}{l}\text { MCN-100+ } \\
\text { Scott-type spray } \\
\text { chamber }\end{array}$ & Q & 100 & 5 & 13 & $0.2-0.3$ & & [15] \\
\hline $\begin{array}{l}\mathrm{As}^{\mathrm{III}}, \mathrm{As}^{\mathrm{V}} \\
\text { MA, DMA }\end{array}$ & $\begin{array}{l}\text { Natural and } \\
\text { spiked urine }\end{array}$ & $\begin{array}{l}\text { AE (Nucleosil SB; } \\
\text { 150x1 mm, } 5 \mu \mathrm{m}) \\
20 \mathrm{mM} \mathrm{NH}_{4} \mathrm{H}_{2} \mathrm{PO}_{4} / \\
\left(\mathrm{NH}_{4}\right)_{2} \mathrm{HPO}_{4}(\mathrm{pH} 5.2)\end{array}$ & $\begin{array}{l}\text { UV nano-TiO2 } \\
\text { photooxidation } \\
+\mathrm{HG}\end{array}$ & Q & 100 & 10 & 15 & $0.17-0.37$ & & [16] \\
\hline $\begin{array}{l}\mathrm{As}^{\mathrm{III}}, \mathrm{As}^{\mathrm{V}} \\
\mathrm{MA}, \mathrm{DMA} \\
\mathrm{AB}\end{array}$ & $\begin{array}{l}\text { Diluted } \\
\text { groundwater }\end{array}$ & $\begin{array}{l}\text { IC (AG-11/AS-11; } \\
50 \times 2 \mathrm{~mm} / 250 \times 2 \mathrm{~mm}) \\
\mathrm{NH}_{4} \mathrm{NO}_{3} \text { gradient }(\mathrm{pH} \\
7.6-8.3)\end{array}$ & $\begin{array}{l}\text { PFA-50+ } \\
\text { Scott-type } \\
\text { cooled }\left(2-5^{\circ} \mathrm{C}\right) \\
\text { spray chamber }\end{array}$ & $\begin{array}{l}\mathrm{SF} \\
(\mathrm{LR})\end{array}$ & 300 & 25 & 10 & $\begin{array}{l}0.005- \\
0.010\end{array}$ & $\begin{array}{l}\mathrm{PO}_{4} \text {-excess in the } \\
\text { injected sample to } \\
\text { eliminate reduction of } \\
\mathrm{As}^{\mathrm{V}} \text { to } \mathrm{As}^{\mathrm{III}}\end{array}$ & [17] \\
\hline Arsenosugars & Algal extract & $\begin{array}{l}\text { AE (Nucleosil SB } \\
100 \times 2.1 \mathrm{~mm}, 5 \mu \mathrm{m}) \\
60 \mathrm{mM} \mathrm{NH}_{4} \mathrm{H}_{2} \mathrm{PO}_{4} \\
(\mathrm{pH} 5.9)\end{array}$ & $\begin{array}{l}\text { PFA-ST+low } \\
\text { volume cyclonic } \\
\text { spray chamber }\end{array}$ & $\begin{array}{c}\text { CRC } \\
\text { (no gas) }\end{array}$ & 200 & 2 & 5 & 0.2 & & [18] \\
\hline
\end{tabular}


Table 5. Selected applications of small-bore HPLC coupled to ICPMS for speciation analysis of selenium.

\begin{tabular}{|c|c|c|c|c|c|c|c|c|c|c|}
\hline Analytes $^{\mathrm{a}}$ & Sample & HPLC $^{b}$ & Interface & $\mathrm{ICPMS}^{\mathrm{c}}$ & 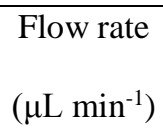 & $\begin{array}{c}\text { Volume } \\
(\mu \mathrm{l})\end{array}$ & $\begin{array}{l}\text { Time } \\
\text { (min) }\end{array}$ & $\begin{array}{l}\mathrm{LOD}^{\mathrm{d}} \\
(\mu \mathrm{g} / \mathrm{l})\end{array}$ & Notes & Ref \\
\hline $\begin{array}{l}\text { SeMet, TMSe } \\
\text { MeSeMet } \\
\text { MeSeCys } \\
\text { SeGaba }\end{array}$ & Urine & $\begin{array}{l}\text { IP-RP }(\mathrm{C} 8 ; 100 \times 1 \mathrm{~mm}, \\
3 \mu \mathrm{m}) \\
20 \% \mathrm{MeOH}+\mathrm{HFBA}\end{array}$ & $\begin{array}{l}\text { Home-made } \\
\text { direct injection } \\
\text { nebulizer [75] }\end{array}$ & Q & 50 & 3 & $10-20$ & $0.8-1.7^{\mathrm{e}}$ & & [20] \\
\hline $\begin{array}{l}\text { Se-AA and } \\
\text { urinary Se- } \\
\text { metabolites }\end{array}$ & $\begin{array}{l}\text { Selenized } \\
\text { garlic; rat urine }\end{array}$ & $\begin{array}{l}\text { GP (GS320A; 150x0.5 } \\
\text { mm) } \\
\mathrm{NH}_{4} \mathrm{Ac}(\mathrm{pH} 6.5)\end{array}$ & $\begin{array}{l}\text { Home-made } \\
\text { micronebulizer+ } \\
\text { evaporation } \\
\text { chamber [27] }\end{array}$ & $\mathrm{Q}$ & 2 & 0.100 & $15-20$ & - & & {$[21]$} \\
\hline $\begin{array}{l}\text { SeMet } \\
\text { SeCys }\end{array}$ & Human serum & $\begin{array}{l}\mathrm{RP}(\mathrm{C} 18 \mathrm{BDS} ; 150 \times 0.3 \\
\mathrm{mm}, 3 \mu \mathrm{m}) \\
\mathrm{CH}_{3} \mathrm{CN} \text { gradient }+ \text { TFA }\end{array}$ & $\begin{array}{l}\text { Home-made } \\
\text { micronebulizer+ } \\
\text { evaporation [27] }\end{array}$ & $\begin{array}{l}\mathrm{CRC} \\
\left(\mathrm{H}_{2}\right)\end{array}$ & 4 & 0.2 & 20 & $\begin{array}{c}0.1-0.5 \\
\mathrm{ng} / \mathrm{g}^{\mathrm{e}}\end{array}$ & $\begin{array}{l}\text { Prior proteolytic } \\
\text { digestion and } \\
\text { fractionation by SEC; }\end{array}$ & {$[22]$} \\
\hline
\end{tabular}

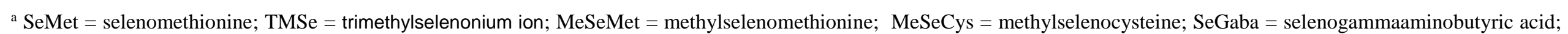
Se-AA = selenoamino acids; GPx = glutathione peroxidase; SelP = selenoprotein P; SeAlb = seleno-albumin.

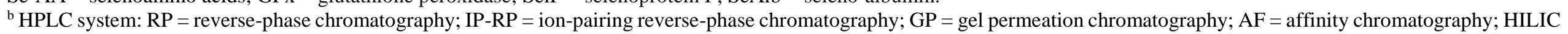
$=$ hydrophilic interaction chromatography.

${ }^{\mathrm{c}}$ ICPMS instrument: $\mathrm{Q}=$ quadrupole; $\mathrm{SF}=$ sector field $(\mathrm{LR}=$ low resolution, $\mathrm{MR}=$ medium resolution, $\mathrm{HR}=$ high resolution); $\mathrm{CRC}=$ collision/reaction cell.

${ }^{\mathrm{d}}$ LOD $=$ limit of detection. Values, unless otherwise stated, refer to instrumental LOD.

${ }^{\mathrm{e}}$ Method detection limit. 


\begin{tabular}{|c|c|c|c|c|c|c|c|c|c|c|}
\hline & & & chamber & & & & & & $\begin{array}{l}\text { quantification by } \\
\text { speciated ID }\end{array}$ & \\
\hline $\begin{array}{l}\text { Se-proteins } \\
\text { GPx, SelP, } \\
\text { SeAlb }\end{array}$ & Human serum & $\begin{array}{l}\mathrm{AF} \text { (HEP and BLUE; } \\
50 \times 1 \mathrm{~mm}, 34 \mu \mathrm{m}) \\
\mathrm{NH}_{4} \mathrm{Ac} \text { gradient }(\mathrm{pH} 7)\end{array}$ & $\begin{array}{l}\text { High-efficiency } \\
\text { nebulisation/ } \\
\text { MD APEX }\end{array}$ & $\begin{array}{l}\text { SF } \\
(\mathrm{HR})\end{array}$ & 300 & 5 & 7 & $2.5^{\mathrm{e}}$ & $\begin{array}{l}\text { Automated exclusion } \\
\text { of the BLUE column } \\
\text { during the elution of } \\
\text { SelP; quantification by } \\
\text { on-line ID }\end{array}$ & [23] \\
\hline SelP & $\begin{array}{l}\text { Human plasma } \\
\text { (purified protein } \\
\text { fraction) }\end{array}$ & $\begin{array}{l}\mathrm{RP}(\mathrm{C} 4 ; 150 \mathrm{x} 1 \mathrm{~mm}, 5 \\
\mu \mathrm{m}) \\
\text { MeOH gradient +TFA }\end{array}$ & $\begin{array}{l}\mathrm{MCN}+\text { heated } \\
\left(100^{\circ} \mathrm{C}\right) \text { spray } \\
\text { chamber/MD }\end{array}$ & Q & 50 & 3 & 25 & 150 & & [24] \\
\hline Se-peptides & $\begin{array}{l}\text { Tryptic digest } \\
\text { of SIP18 } \\
\text { protein }\end{array}$ & $\begin{array}{l}\text { RP (C18 PepMap 100; } \\
\text { 150x0.075 mm, } 3 \mu \mathrm{m}) \\
\mathrm{CH}_{3} \mathrm{CN} \text { gradient }+ \text { TFA }\end{array}$ & $\begin{array}{l}\text { nanoflow } \\
\text { nebulizer nDS- } \\
\text { 200+evaporation } \\
\text { chamber }\end{array}$ & $\begin{array}{l}\mathrm{CRC} \\
\left(\mathrm{H}_{2}\right)\end{array}$ & 0.300 & 0.011 & 20 & 2.3 & $\begin{array}{l}\text { NanoHPLC/ESI-MS } \\
\text { used for selenopeptide } \\
\text { identification }\end{array}$ & [26] \\
\hline
\end{tabular}


Table 6. Selected applications of small-bore HPLC coupled to ICPMS for speciation analysis of $\mathrm{Cd}, \mathrm{Cu}$ and $\mathrm{Zn}$.

\begin{tabular}{|c|c|c|c|c|c|c|c|c|c|c|}
\hline Analytes $^{\mathrm{a}}$ & Sample & HPLC $^{b}$ & Interface & $\mathrm{ICPMS}^{\mathrm{c}}$ & 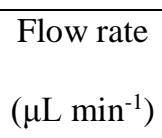 & $\begin{array}{l}\text { Volume } \\
(\mu \mathrm{l})\end{array}$ & $\begin{array}{l}\text { Time } \\
\text { (min) }\end{array}$ & $\begin{array}{l}\mathrm{LOD}^{\mathrm{d}} \\
(\mu \mathrm{g} / \mathrm{l}))\end{array}$ & Notes & Ref \\
\hline Cd-MTs & $\begin{array}{l}\text { Rabbit liver } \\
\text { MT-2 }\end{array}$ & $\begin{array}{l}\mathrm{RP}(\mathrm{C} 8 ; 150 \mathrm{x} 1 \mathrm{~mm}, 5 \\
\mu \mathrm{m}) \\
\mathrm{MeOH} \text { gradient } \\
+\mathrm{NH}_{4} \mathrm{Ac}(\mathrm{pH} 6)\end{array}$ & $\begin{array}{l}\text { DIN } \\
\left(+\mathrm{O}_{2} \text { in the }\right. \\
\text { nebulizer gas })\end{array}$ & Q & 40 & 5 & 48 & $\approx 10$ & $\begin{array}{l}\text { Preconcentration } \\
\text { step of } 2 \text { min before } \\
\text { gradient elution }\end{array}$ & [38] \\
\hline $\begin{array}{l}\text { Cd-MTs } \\
\text { Cu-MTs } \\
\text { Zn-MTs }\end{array}$ & $\begin{array}{l}\text { Rat liver and } \\
\text { kidney tissues }\end{array}$ & $\begin{array}{l}\mathrm{RP}(\mathrm{C} 8150 \times 1 \mathrm{~mm}, 5 \\
\mu \mathrm{m}) \\
\mathrm{CH}_{3} \mathrm{CN} \text { gradient } \\
+\mathrm{NH}_{4} \mathrm{Ac}(\mathrm{pH} 6)\end{array}$ & $\begin{array}{l}\text { MicroMist+ } \\
\text { cooled }\left(2^{\circ} \mathrm{C}\right) \\
\text { spray chamber } \\
\left(+\mathrm{O}_{2} \text { in the }\right. \\
\text { nebulizer gas })\end{array}$ & Q & 40 & 5 & 40 & - & $\begin{array}{l}\text { Prior fractionation } \\
\text { by SEC, } \\
\text { liophilization and } \\
\text { desalting; peak } \\
\text { identification by } \\
\text { parallel ESI triple- } \\
\text { quadrupole MS }\end{array}$ & [39-40] \\
\hline $\begin{array}{l}\mathrm{Cu} \text {-proteins } \\
\text { Zn-proteins }\end{array}$ & $\begin{array}{l}\text { Red blood cell } \\
\text { extracts }\end{array}$ & $\begin{array}{l}\mathrm{RP}(\mathrm{C} 8150 \times 0.3 \mathrm{~mm}, \\
3.5 \mu \mathrm{m})\end{array}$ & $\begin{array}{l}\text { Modified CEI } \\
100 \text { nebuliser }+\end{array}$ & $\begin{array}{l}\mathrm{CRC} \\
\left(\mathrm{H}_{2}\right)\end{array}$ & 3 & $0.01-2$ & 60 & $\begin{array}{c}0.43(\mathrm{Cu}) \\
2(\mathrm{Zn})\end{array}$ & & [41] \\
\hline
\end{tabular}

${ }^{\text {a }}$ Cd-MTs = cadmium metallothioneins; $\mathrm{Cu}-\mathrm{MTs}=$ copper metallothioneins ; Zn-MTs = zinc metallothioneins

${ }^{\mathrm{b}}$ HPLC system: RP = reverse-phase chromatography; GP = gel permeation chromatography.

${ }^{\mathrm{c}}$ ICPMS instrument: $\mathrm{Q}=$ quadrupole; $\mathrm{CRC}=$ collision/reaction cell.

${ }^{\mathrm{d}}$ LOD $=$ limit of detection. Values, unless otherwise stated, refer to instrumental LOD. 


\begin{tabular}{|l|l|l|l|l|l|l|l|l|l|}
\hline & & $\begin{array}{l}\text { MeOH gradient } \\
+\mathrm{NH}_{4} \mathrm{Ac}(\mathrm{pH} 7.4)\end{array}$ & $\begin{array}{l}\text { home-made } \\
\text { evaporation } \\
\text { chamber [46] }\end{array}$ & & & & & & \\
\hline Cu-MT & $\begin{array}{l}\text { Mouse tissue } \\
\text { supernatants }\end{array}$ & $\begin{array}{l}\text { GP (KW802.5; 250x2 } \\
\mathrm{mm})\end{array}$ & $\begin{array}{l}\text { AriMist+ } \\
\text { cyclonic spray } \\
\text { chamber }\end{array}$ & CRC $(\mathrm{pH} 7.2)$ & 40 & 5 & 20 & - & {$[42]$} \\
\hline
\end{tabular}


Table 7. Selected applications of small-bore HPLC coupled to ICPMS for speciation analysis of $\mathrm{Cr}, \mathrm{Hg}$ and $\mathrm{Pb}$

\begin{tabular}{|c|c|c|c|c|c|c|c|c|c|c|}
\hline Analytes $^{\mathrm{a}}$ & Sample & HPLC $^{b}$ & Interface & $\mathrm{ICPMS}^{\mathrm{c}}$ & $\begin{array}{l}\text { Flow rate } \\
\left(\mu \mathrm{L} \min ^{-1}\right)\end{array}$ & $\begin{array}{c}\text { Volume } \\
(\mu \mathrm{l})\end{array}$ & $\begin{array}{l}\text { Time } \\
(\min )\end{array}$ & $\begin{array}{l}\mathrm{LOD}^{\mathrm{d}} \\
(\mu \mathrm{g} / \mathrm{l})\end{array}$ & Notes & Ref \\
\hline $\mathrm{Cr}^{\mathrm{IIII}}, \mathrm{Cr}^{\mathrm{VI}}$ & Urine CRMs & $\begin{array}{l}\text { IC }(\mathrm{AS}-11 ; 250 \mathrm{x} 2 \mathrm{~mm}, \\
13 \mu \mathrm{m}) \\
7 \mathrm{mM} \mathrm{PDC}+9.6 \mathrm{mM} \\
\mathrm{LiOH}(\mathrm{pH} 7.7)\end{array}$ & DIN & Q & 150 & 2.5 & 20 & $1.1-1.2$ & $\begin{array}{l}\mathrm{Cr}^{\mathrm{III}} \text { was pre- } \\
\text { complexed with } \mathrm{PDC}^{\mathrm{s}} \\
\text { by warming to } 65^{\circ} \mathrm{C} \\
\text { for two hours }\end{array}$ & [31] \\
\hline $\mathrm{Cr}^{\mathrm{IIII}}, \mathrm{Cr}^{\mathrm{VI}}$ & $\begin{array}{l}\text { Industrial process } \\
\text { solutions }\end{array}$ & $\begin{array}{l}\mathrm{AE}(\mathrm{ANX}-3202 ; 20 \times 2 \mathrm{~mm}) \\
60 \mathrm{mM} \mathrm{HNO}_{3}\end{array}$ & $\begin{array}{l}\text { MCN-100+ } \\
\text { Scott-type } \\
\text { spray chamber }\end{array}$ & $\begin{array}{c}\mathrm{SF} \\
(\mathrm{MR})\end{array}$ & 100 & 20 & 5 & $0.05-0.12$ & & {$[3]$} \\
\hline $\begin{array}{l}\mathrm{Hg}^{2+}, \mathrm{MeHg}^{+} \\
\mathrm{EtHg}^{+}, \mathrm{PhHg}^{+} \\
\mathrm{Pb}^{2+},(\mathrm{Et})_{3} \mathrm{~Pb}^{+} \\
(\mathrm{Me})_{3} \mathrm{~Pb}^{+}\end{array}$ & $\begin{array}{l}\text { Natural and } \\
\text { spiked urine }\end{array}$ & $\begin{array}{l}\text { IP-RP }(\mathrm{C} 1850 \times 1.6 \mathrm{~mm} / \\
150 \times 1.6 \mathrm{~mm}) \\
20 \% \mathrm{CH}_{3} \mathrm{CN}+5 \mathrm{mM} \\
\mathrm{C}_{5} \mathrm{H}_{11} \mathrm{SO}_{3} \mathrm{NH}_{4}(\mathrm{pH} 3.4)\end{array}$ & DIN & Q & 100 & 2 & $5-11$ & $\begin{array}{l}0.1(\mathrm{~Pb})^{\mathrm{f}} \\
4-8(\mathrm{Hg})^{\mathrm{f}}\end{array}$ & & [33] \\
\hline $\begin{array}{l}\mathrm{Hg}^{2+}, \mathrm{MeHg}^{+}, \\
\mathrm{EtHg}^{+}, \mathrm{PhHg}^{+}\end{array}$ & $\begin{array}{l}\text { Spiked } \\
\text { groundwater, } \\
\text { depurated urban }\end{array}$ & $\begin{array}{l}\mathrm{RP}(\mathrm{C} 18 ; 100 \mathrm{x} 1 \mathrm{~mm}, 3 \mu \mathrm{m}) \\
\mathrm{MeOH} / \mathrm{NH}_{4} \mathrm{Ac} / \mathrm{L}-\mathrm{cystein} \\
\text { gradient (pH 3) }\end{array}$ & MicroMist+ & Q & 70 & 20 & 15 & $\begin{array}{l}0.008- \\
0.032\end{array}$ & $\begin{array}{l}\text { Low recovery for } \\
\text { high saline samples }\end{array}$ & [34] \\
\hline
\end{tabular}

${ }^{\mathrm{a}} \mathrm{Cr}^{\mathrm{III}}=$ trivalent chromium; $\mathrm{Cr}^{\mathrm{VI}}=$ hexavalent chromium.

${ }^{\mathrm{b}}$ HPLC system: IC = ion chromatography; AE = anion exchange chromatography; RP = reverse-phase chromatography; IP-RP = ion-pairing reverse-phase chromatography

${ }^{\mathrm{c}}$ ICPMS instrument: $\mathrm{Q}=$ quadrupole; $\mathrm{SF}=$ sector field ( $\mathrm{LR}=$ low resolution, MR=medium resolution, HR=high resolution).

${ }^{\mathrm{d}} \mathrm{LOD}=$ limit of detection. Values, unless otherwise stated, refer to instrumental LOD.

e PDC $=2,6$-pyridinedicarboxylic acid.

${ }^{\mathrm{f}}$ Method detection limit. 


\begin{tabular}{|l|l|l|l|l|l|l|l|l|}
\hline & wastewater and & & $\begin{array}{l}\text { Scott-type } \\
\text { cooled }\left(2^{\circ} \mathrm{C}\right) \\
\text { seawater }\end{array}$ & & & & & \\
& & & & & & & & \\
\hline
\end{tabular}


Table 8. Selected applications of small-bore HPLC coupled to ICPMS for the determination of other species.

\begin{tabular}{|c|c|c|c|c|c|c|c|c|c|c|}
\hline Analytes & Sample & HPLC $^{a}$ & Interface & ICPMS $^{\mathrm{b}}$ & 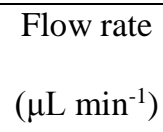 & $\begin{array}{c}\text { Volume } \\
(\mu l)\end{array}$ & $\begin{array}{l}\text { Time } \\
\text { (min) }\end{array}$ & $\begin{array}{l}\mathrm{LOD}^{\mathrm{c}} \\
(\mu \mathrm{g} / \mathrm{l}))\end{array}$ & Notes & Ref \\
\hline $\begin{array}{l}\text { Phospho- } \\
\text { peptides }\end{array}$ & $\begin{array}{l}\text { Tryptic digests } \\
\text { of } \beta \text {-casein, } \\
\text { activated MAP } \\
\text { kinase and } \\
\text { protein kinase A } \\
\text { catalytic subunit }\end{array}$ & $\begin{array}{l}\mathrm{RP}(\mathrm{C} 18 ; 25 \mathrm{x} 0.3 \mathrm{~mm}, 5 \\
\mu \mathrm{m}) \\
\mathrm{CH}_{3} \mathrm{CN} \text { gradient }+\mathrm{TFA}\end{array}$ & $\begin{array}{l}\text { PFA-100+ } \\
\text { low-volume } \\
\text { spray chamber }\end{array}$ & $\begin{array}{c}\mathrm{SF} \\
(\mathrm{MR})\end{array}$ & 4 & 5 & $35-40$ & $\begin{array}{l}\approx 0.1 \\
\text { pmol }\end{array}$ & $\begin{array}{l}\text { Assignment } \\
\text { of the chromatographic } \\
\text { peaks by LC/ESI-MS }\end{array}$ & {$[45]$} \\
\hline $\begin{array}{l}\text { Phospho- } \\
\text { peptides }\end{array}$ & $\begin{array}{l}\text { Tryptic digest } \\
\text { of } \beta \text {-casein }\end{array}$ & $\begin{array}{l}\mathrm{RP}(\mathrm{C} 18150 \mathrm{x} 0.3 \mathrm{~mm}, \\
3.5 \mu \mathrm{m} \text { or } 150 \mathrm{x} 0.1 \mathrm{~mm} \text {, } \\
3.5 \mu \mathrm{m}) \\
\mathrm{CH}_{3} \mathrm{CN} \text { gradient }+\mathrm{TFA}\end{array}$ & $\begin{array}{l}\text { Modified CEI } \\
100 \text { nebuliser + } \\
\text { home-made } \\
\text { evaporation } \\
\text { chamber }\end{array}$ & $\begin{array}{l}\mathrm{CRC} \\
(\mathrm{He})\end{array}$ & $0.5-4$ & $0.01-8$ & 110 & 1.95 & & [46] \\
\hline $\begin{array}{l}\text { Cis-Platin } \\
\text { adducts with }\end{array}$ & $\begin{array}{l}\text { Calf thymus } \\
\text { DNA samples }\end{array}$ & $\begin{array}{l}\mathrm{RP}(\mathrm{C} 8250 \times 2.1 \mathrm{~mm}, 5 \\
\mu \mathrm{m})\end{array}$ & $\begin{array}{l}\text { PFA } \\
\text { micronebulizer }\end{array}$ & $\begin{array}{c}\text { CRC } \\
\text { (no gas) }\end{array}$ & 200 & 20 & 35 & - & Structural & [51] \\
\hline
\end{tabular}

${ }^{\mathrm{a}} \mathrm{HPLC}$ system: IC = ion chromatography; $\mathrm{AE}=$ anion exchange chromatography; $\mathrm{RP}=$ reverse-phase chromatography; IP-RP = ion-pairing reverse-phase chromatography

${ }^{\mathrm{b}}$ ICPMS instrument: $\mathrm{Q}=$ quadrupole; $\mathrm{SF}=$ sector field $(\mathrm{LR}=$ low resolution, $\mathrm{MR}=$ medium resolution, $\mathrm{HR}=$ high resolution); $\mathrm{CRC}=$ collision/reaction cell.

${ }^{\mathrm{c}} \mathrm{LOD}=$ limit of detection. Values, unless otherwise stated, refer to instrumental LOD. 


\begin{tabular}{|c|c|c|c|c|c|c|c|c|c|c|}
\hline $\begin{array}{l}\text { DNA } \\
\text { nucleotides }\end{array}$ & & $\begin{array}{l}60 \mathrm{mM} \mathrm{NH}_{4} \mathrm{Ac}(\mathrm{pH}= \\
5.8)+7.5 \% \mathrm{MeOH}\end{array}$ & & & & & & & $\begin{array}{l}\text { characterization of } \\
\text { adducts by ESI-Q- } \\
\text { TOF-MS }\end{array}$ & \\
\hline Cobalamins & $\begin{array}{l}\text { Pharmaceutical } \\
\text { preparations }\end{array}$ & $\begin{array}{l}\mathrm{RP}(\mathrm{C} 8 ; 150 \mathrm{x} 1 \mathrm{~mm}, 5 \\
\mu \mathrm{m} / 100 \mathrm{x} 1 \mathrm{~mm}, 7 \mu \mathrm{m}) \\
\mathrm{MeOH} \text { gradient }+25 \\
\mathrm{mM} \mathrm{NH}_{4} \mathrm{Ac}(\mathrm{pH} 4)\end{array}$ & $\begin{array}{l}\text { DIN } \\
\left(+\mathrm{O}_{2} \text { in the }\right. \\
\text { nebulizer gas })\end{array}$ & Q & 40 & 5 & 30 & $10-50$ & & [43] \\
\hline Bromate & Drinking waters & $\begin{array}{l}\text { IC (home-made high- } \\
\text { capacity anion } \\
\text { exchanger; } 100 \times 2 \mathrm{~mm} \text { ) } \\
\mathrm{NH}_{4} \mathrm{NO}_{3}(\mathrm{pH} 6)\end{array}$ & $\begin{array}{l}\text { V-groove } \\
\text { nebulizer }\end{array}$ & Q & 500 & 885 & $8-15$ & $0.05^{\mathrm{a}}$ & $\begin{array}{l}\text { Retention time and } \\
\text { background level } \\
\text { depended on the } \\
\text { sample composition }\end{array}$ & [70] \\
\hline $\mathrm{Fe}, \mathrm{Cu}, \mathrm{Se}$ & $\begin{array}{l}\text { Human plasma } \\
\text { and serum } \\
\text { samples }\end{array}$ & $\begin{array}{l}\text { AE (SAX1-S; } 50 \text { x } 1 \\
\text { mm) } \\
\text { Buffer A: } 10 \mathrm{mM} \text { Tris } \\
\text { (pH 7.4) } \\
\text { Buffer B: } 1 \mathrm{M} \\
\text { ammonium acetate in } \\
10 \text { mM Tris (pH 7.4) }\end{array}$ & $\begin{array}{l}\text { MicroMist } \\
\text { nebulizer / low- } \\
\text { volume Cinnabar } \\
\text { Cyclonic spray } \\
\text { chamber }\end{array}$ & $\begin{array}{l}\mathrm{CRC} \\
\left(8 \% \mathrm{H}_{2}\right. \\
\text { in } \mathrm{He})\end{array}$ & 200 & 100 & $<10$ & - & $\begin{array}{l}\text { Tandem LC mode was } \\
\text { used to save the time } \\
\text { needed for washing } \\
\text { and regenerating the } \\
\text { columns. }\end{array}$ & {$[60]$} \\
\hline
\end{tabular}

a Method detection limit. 


\section{Future trends.}

Future trends in the use of small-bore HPLC columns coupled to ICPMS lie in the accomplishment of lower limits of detection and faster separations as compared with normal bore HPLC. The need of the reduction in detection limits is noticeable in the bibliography because of the intensive search to reduce extra column contribution and dead volumes in the whole system. This is achieved by the optimization of the system components; use of special micronebulizers, chromatographic columns with small particle sizes, minimizing tubing length and id.

The use of UHPLC coupled to ICPMS is an approach to get faster separations with the use of stationary phases with small particle size $(1.7 \mu \mathrm{m})$ but working at high pressures. In addition, the use of capillary columns in fast LC gives us the advantage of the absence of additional band broadening due to frictional heating (use of very low nano-flow rates) [76].

The benefit of temperature in liquid chromatography is evidenced [77] and it could be another approach to achieve faster analysis and lower detection times with small-bore columns coupled to ICPMS. The influence of column temperature in these columns has only been employed in two works with a maximum temperature of $65^{\circ} \mathrm{C}$, being the main reason the challenge to find an adequate high temperature resistant stationary phase. Gammelgaard et al. examined temperatures between 20 and $60{ }^{\circ} \mathrm{C}$ in selenium speciation, noticing that retention times decreased for all species with increasing temperature, but due to the peak shapes and resolution deteriorated at high temperatures, the temperature was kept constant at $25^{\circ} \mathrm{C}$ to avoid any possible decomposition of the species [20]. Porous graphitic carbon stationary phase is composed by layers of carbon arranged as hexagons and it supports temperatures as high as $250^{\circ} \mathrm{C}$, it has the capability of separating organic as well as pure inorganic species and it could be an option to carry out determinations at high temperatures. It has been used as stationary phase to carry out the separation of arsenic compounds [78] at room temperature. 


\section{Acknowledgements}

Amanda Terol thanks the Fundación Ramón Areces for the postdoctoral grant (25th edition).

This work was carried out in the frame of the Italian National Project PRIN-2010AXENJ8.

\section{References}

[1] D.M. Templeton, F. Ariese, R. Cornelis, L.G. Danielsson, H. Muntau, H.P. Van Leeuwen, R. Łobiński, Guidelines for terms related to chemical speciation and fractionation of elements. Definitions, structural aspects, and methodological approaches (IUPAC recommendations 2000), Pure Appl. Chem. 72 (2000) 1453-1470.

[2] M. Leermakers, W. Baeyens, M. De Gieter, B. Smedts, C. Meert, H.C. De Bisschop, R. Morabito, P. Quevauviller, Toxic arsenic compounds in environmental samples: Speciation and validation, Trends Anal. Chem. 25 (2006) 1-10.

[3] F. Vanhaecke, S. Saverwyns, G.D. Wannemacker, L. Moens, R. Dams, Comparison of the application of higher mass resolution and cool plasma conditions to avoid spectral interferences in $\mathrm{Cr}(\mathrm{III}) / \mathrm{Cr}(\mathrm{VI})$ speciation by means of high-performance liquid chromatography - inductively coupled plasma mass spectrometry, Anal. Chim. Acta 419 (2000) 55-64.

[4] J. Szpunar, R. Lobinski, Hyphenated Techniques in Speciation Analysis, first ed., RSC Publishing, Cambridge, 2003.

[5] B. Michalke, The coupling of LC to ICP-MS in element speciation: I. General aspects, Trends Anal. Chem. 21 (2002) 142-153.

[6] B. Michalke, The coupling of LC to ICP-MS in element speciation - Part II: Recent trends in application, Trends Anal. Chem. 21 (2002) 154-165.

[7] K.L. Ackley, K.L. Sutton, J.A. Caruso, Comparison of nebulizers for microbore LC-ICP-MS with mobile phases containing methanol, J. Anal. At. Spectrom. 15 (2000) 1069-1073.

[8] S. Saverwyns, K. Van Hecke, F. Vanhaecke, L. Moens, R. Dams, Evaluation of a commercially available microbore anion exchange column for chromium speciation with detection by ICP-mass spectrometry and hyphenation with microconcentric nebulization, Fresen. J. Anal. Chem. 363 (1999) 490-494.

[9] H. Garraud, A. Woller, P. Fodor, O.F.X. Donard, Trace elemental speciation by HPLC using microbore columns hyphenated to atomic spectrometry: A review, Analusis 25 (1997) 25-31. 
[10] Z. Stefánka, G. Koellensperger, G. Stingeder, S. Hann, Down-scaling narrowbore LC-ICP-MS to capillary LC-ICP-MS: A comparative study of different introduction systems, J. Anal. At. Spectrom. 21 (2006) 86-89.

[11] S.A. Pergantis, E.M. Heithmar, T.A. Hinners, Speciation of arsenic animal feed additives by microbore high-performance liquid chromatography with inductively coupled plasma mass spectrometry, Analyst 122 (1997) 1063-1068.

[12] S. Wangkarn, S.A. Pergantis, High-speed separation of arsenic compounds using narrow-bore high-performance liquid chromatography on-line with inductively coupled plasma mass spectrometry, J. Anal. At. Spectrom. 15 (2000) 627-633.

[13] Á. Woller, H. Garraud, J. Boisson, A.M. Dorthe, P. Fodor, O.F.X. Donard, Simultaneous speciation of redox species of arsenic and selenium using an anion-exchange microbore column coupled with a microconcentric nebulizer and an inductively coupled plasma mass spectrometer as detector, J. Anal. At. Spectrom. 13 (1998) 141-149.

[14] A. Castillo, A.F. Roig-Navarro, O.J. Pozo, Capabilities of microbore columns coupled to inductively coupled plasma mass spectrometry in speciation of arsenic and selenium, J. Chromatogr. A $1202(2008)$ 132-137.

[15] Y.C. Sun, Y.S. Lee, T.L. Shiah, P.L. Lee, W.C. Tseng, M.H. Yang, Comparative study on conventional and low-flow nebulizers for arsenic speciation by means of microbore liquid chromatography with inductively coupled plasma mass spectrometry, J. Chromatogr. A 1005 (2003) 207-213.

[16] Y.C. Sun, Y.J. Chen, Y.N. Tsai, Determination of urinary arsenic species using an on-line nanoTiO2 photooxidation device coupled with microbore LC and hydride generation-ICP-MS system, Microchem. J. 86 (2007) 140-145.

[17] A.A. Ammann, Arsenic speciation by gradient anion exchange narrow bore ion chromatography and high resolution inductively coupled plasma mass spectrometry detection, J. Chromatogr. A 1217 (2010) 2111-2116.

[18] J.L. Todolí, M. Grotti, Fast determination of arsenosugars in algal extracts by narrow bore highperformance liquid chromatography-inductively coupled plasma mass spectrometry, J. Chromatogr. A 1217 (2010) 7428-7433.

[19] S.A. Pergantis, E.M. Heithmar, T.A. Hinners, Microscale flow-injection and microbore highperformance liquid-chromatography coupled with inductively-coupled plasma-mass spectrometry via a high-efficiency nebulizer, Anal. Chem. 67 (1995) 4530-4535. 
[20] B. Gammelgaard, L. Bendahl, U. Sidenius, O. Jøns, Selenium speciation in urine by ion-pairing chromatography with perfluorinated carboxylic acids and ICP-MS detection, J. Anal. At. Spectrom. 17 (2002) 570-575.

[21] Y. Ogra, K.T. Suzuki, Speciation of selenocompounds by capillary HPLC coupled with ICP-MS using multi-mode gel filtration columns, J. Anal. At. Spectrom. 20 (2005) 35-39.

[22] J.R. Encinar, D. Schaumlöffel, Y. Ogra, R. Lobinski, Determination of selenomethionine and selenocysteine in human serum using speciated isotope dilution-capillary HPLC-inductively coupled plasma collision cell mass spectrometry, Anal. Chem. 76 (2004) 6635-6642.

[23] P. Jitaru, M. Roman, G. Cozzi, P. Fisicaro, P. Cescon, C. Barbante, Speciation analysis of selenoproteins in human serum by microbore affinity-HPLC hyphenated to ICP-sector field-MS using a high efficiency sample introduction system, Microchim. Acta 166 (2009) 319-327.

[24] L. Bendahl, B. Gammelgaard, Sample introduction systems for reversed phase LC-ICP-MS of selenium using large amounts of methanol - Comparison of systems based on membrane desolvation, a spray chamber and direct injection, J. Anal. At. Spectrom. 20 (2005) 410-416.

[25] J. Far, H. Preud'homme, R. Lobinski, Detection and identification of hydrophilic selenium compounds in selenium-rich yeast by size exclusion-microbore normal-phase HPLC with the on-line ICP-MS and electrospray Q-TOF-MS detection, Anal. Chim. Acta 657 (2010) 175-190.

[26] P. Giusti, R. Lobinski, J. Szpunar, D. Schaumlöffel, Development of a nebulizer for a sheathless interfacing of NanoHPLC and ICPMS, Anal. Chem. 78 (2006) 965-971.

[27] D. Schaumlöffel, J.R. Encinar, R. Łobiński, Development of a Sheathless Interface between Reversed-Phase Capillary HPLC and ICPMS via a Microflow Total Consumption Nebulizer for Selenopeptide Mapping, Anal. Chem. 75 (2003) 6837-6842.

[28] L. Bendahl, S. Stürup, B. Gammelgaard, S.H. Hansen, UPLC-ICP-MS - A fast technique for speciation analysis, J. Anal. At. Spectrom. 20 (2005) 1287-1289.

[29] J.M. Marchante-Gayón, C. Thomas, I. Feldmann, N. Jakubowski, Comparison of different nebulizers and chromatographic techniques for the speciation of selenium in nutritional commercial supplements by hexapole collision and reaction cell ICP-MS, J. Anal. At. Spectrom. 15 (2000) 10931102.

[30] S.C.K. Shum, R.S. Houk, Elemental speciation by anion exchange and size exclusion chromatography with detection by inductively coupled plasma mass spectrometry with direct injection nebulization, Anal. Chem. 65 (1993) 2972-2976.

[31] G. Zoorob, M. Tomlinson, J. Wang, J. Caruso, Evaluation of the direct injection nebulizer in the coupling of high-performance liquid chromatography to inductively coupled plasma mass spectrometry, J. Anal. At. Spectrom. 10 (1995) 853-858. 
[32] M.J. Powell, D.W. Boomer, D.R. Wiederin, Determination of chromium species in environmental samples using high-pressure liquid chromatography direct injection nebulization and inductively coupled plasma mass spectrometry, Anal. Chem. 67 (1995) 2474-2478.

[33] S.C.K. Shum, H.M. Pang, R.S. Houk, Speciation of mercury and lead compounds by microbore column liquid chromatography-inductively coupled plasma mass spectrometry with direct injection nebulization, Anal. Chem. 64 (1992) 2444-2450.

[34] A. Castillo, A.F. Roig-Navarro, O.J. Pozo, Method optimization for the determination of four mercury species by micro-liquid chromatography-inductively coupled plasma mass spectrometry coupling in environmental water samples, Anal. Chim. Acta 577 (2006) 18-25.

[35] B.W. Acon, J.A. McLean, A. Montaser, A direct injection high efficiency nebulizer interface for microbore high-performance liquid chromatography-inductively coupled plasma mass spectrometry, J. Anal. At. Spectrom. 16 (2001) 852-857.

[36] X. Chen, C. Han, H. Cheng, Y. Wang, J. Liu, Z. Xu, L. Hu, Rapid speciation analysis of mercury in seawater and marine fish by cation exchange chromatography hyphenated with inductively coupled plasma mass spectrometry, J. Chromatogr. A 1314 (2013) 86-93.

[37] S.S. de Souza, A.D. Campiglia, F. Barbosa, A simple method for methylmercury, inorganic mercury and ethylmercury determination in plasma samples by high performance liquid chromatography-cold-vapor-inductively coupled plasma mass spectrometry, Anal. Chim. Acta 761 (2013) 11-17.

[38] H. Chassaigne, R. Lobinski, Speciation of metal complexes with biomolecules by reversed-phase HPLC with ion-spray and inductively coupled plasma mass spectrometric detection, Fresen. J. Anal. Chem. 361 (1998) 267-273.

[39] K. Poleć, O. García-Arribas, M. Percz-Calvo, J. Szpunar, B. Ribas-Ozonas, R. ŁObinski, Identification of cadmium-bioinduced ligands in rat liver using parallel HPLC-ICP-MS and HPLCelectrospray MS, J. Anal. At. Spectrom. 15 (2000) 1363-1368.

[40] K. Poleć, M. Peréz-Calvo, O. García-Arribas, J. Szpunar, B. Ribas-Ozonas, R. Łobiński, Investigation of metal complexes with metallothionein in rat tissues by hyphenated techniques, J. Inorg. Biochem. 88 (2002) 197-206.

[41] M. Montes-Bayon, D. Pröfrock, A. Sanz-Medel, A. Prange, Direct comparison of capillary electrophoresis and capillary liquid chromatography hyphenated to collision-cell inductively coupled plasma mass spectrometry for the investigation of $\mathrm{Cd}-, \mathrm{Cu}$ - and $\mathrm{Zn}$-containing metalloproteins, J. Chromatogr. A 1114 (2006) 138-144. 
[42] T. Miyayama, Y. Ogra, Y. Osima, K.T. Suzuki, Narrow-bore HPLC-ICP-MS for speciation of copper in mutant mouse neonates bearing a defect in $\mathrm{Cu}$ metabolism, Anal. Bioanal. Chem. 390 (2008) 1799-1803.

[43] H. Chassaigne, R. Lobiński, Determination of cobalamins and cobinamides by microbore reversed-phase HPLC with spectrophotometric, ion-spray ionization MS and inductively coupled plasma MS detection, Anal. Chim. Acta 359 (1998) 227-235.

[44] E.G. Yanes, N.J. Miller-Ihli, Use of a parallel path nebulizer for capillary-based microseparation techniques coupled with an inductively coupled plasma mass spectrometer for speciation measurements, Spectrochim. Acta, Part B 59 (2004) 883-890.

[45] M. Wind, M. Edler, N. Jakubowski, M. Linscheid, H. Wesch, W.D. Lehmann, Analysis of protein phosphorylation by capillary liquid chromatography coupled to element mass spectrometry with 31P detection and to electrospray mass spectrometry, Anal. Chem. 73 (2001) 29-35.

[46] D. Pröfrock, P. Leonhard, W. Ruck, A. Prange, Development and characterisation of a new interface for coupling capillary LC with collision-cell ICP-MS and its application for phosphorylation profiling of tryptic protein digests, Anal. Bioanal. Chem. 381 (2005) 194-204.

[47] M. Wind, A. Eisenmengerb, W.D. Lehmann, Modified direct injection high efficiency nebulizer with minimized dead volume for the analysis of biological samples by micro- and nano-LC-ICP-MS, J. Anal. At. Spectrom. 17 (2002) 21-26.

[48] G. Rozing, Trends in HPLC Column Formats - Microbore, Nanobore and Smaller, LC-GC 6 (2003) 1-7.

[49] N. Wu, J.A. Lippert, M.L. Lee, Practical aspects of ultrahigh pressure capillary liquid chromatography, J. Chromatogr. A 911 (2001) 1-12.

[50] D.F. Thompson, F. Michopoulos, C.J. Smith, C.J. Duckett, R.W. Wilkinson, P. Jarvis, I.D. Wilson, Profiling biological samples using ultra performance liquid chromatography-inductively coupled plasma-mass spectrometry (UPLC-ICP-MS) for the determination of phosphorus and sulfurcontaining metabolites, Mol. BioSyst. 7 (2011) 1149-1157.

[51] D. García Sar, M. Montes-Bayón, E.B. González, A. Sanz-Medel, Speciation studies of cis-platin adducts with DNA nucleotides via elemental specific detection ( $\mathrm{P}$ and $\mathrm{Pt}$ ) using liquid chromatography-inductively coupled plasma-mass spectrometry and structural characterization by electrospray mass spectrometry, J. Anal. At. Spectrom. 21 (2006) 861-868.

[52] A.A. Ammann, Speciation of heavy metals in environmental water by ion chromatography coupled to ICP-MS, Anal. Bioanal. Chem. 372 (2002) 448-452. 
[53] A. Castillo, A.F. Roig-Navarro, O.J. Pozo, Secondary interactions, an unexpected problem emerged between hydroxyl containing analytes and fused silica capillaries in anion-exchange microliquid chromatography, J. Chromatogr. A 1172 (2007) 179-185.

[54] G.E.M. Hall, J.C. Pelchat, G. Gauthier, Stability of inorganic arsenic(III) and arsenic(V) in water samples, J. Anal. At. Spectrom. 14 (1999) 205-213.

[55] K. Shigeta, K. Sato, N. Furuta, Determination of selenoprotein P in submicrolitre samples of human plasma using micro-affinity chromatography coupled with low flow ICP-MS, J. Anal. At. Spectrom. 22 (2007) 911-916.

[56] K. Shigeta, K. Matsumura, Y. Suzuki, A. Shinohara, N. Furuta, Distribution and dynamic pathway of selenium species in selenium-deficient mice injected with 82Se-enriched selenite, Anal. Sci. 24 (2008) 1117-1122.

[57] D.G. Sar, M. Montes-Bayón, E.B. González, A. Sanz-Medel, Speciation studies of cis-platin adducts with DNA nucleotides via elemental specific detection ( $\mathrm{P}$ and $\mathrm{Pt}$ ) using liquid chromatography-inductively coupled plasma-mass spectrometry and structural characterization by electrospray mass spectrometry, J. Anal. At. Spectrom. 21 (2006) 861-868.

[58] L. Wang, S.W. May, R.F. Browner, S.H. Pollock, Low-flow interface for liquid chromatographyinductively coupled plasma mass spectrometry speciation using an oscillating capillary nebulizer, J. Anal. At. Spectrom. 11 (1996) 1137-1146.

[59] M.W. Raynor, G.D. Dawson, M. Balcerzak, W.G. Pretorius, L. Ebdon, Electrospray nebulisation interface for micro-high performance liquid chromatography-inductively coupled plasma mass spectrometry, J. Anal. At. Spectrom. 12 (1997) 1057-1064.

[60] M. Malavolta, F. Piacenza, A. Basso, R. Giacconi, L. Costarelli, S. Pierpaoli, E. Mocchegiani, Speciation of trace elements in human serum by micro anion exchange chromatography coupled with inductively coupled plasma mass spectrometry, Anal. Biochem. 421 (2012) 16-25.

[61] D. Schaumlöffel, A. Prange, A new interface for combining capillary electrophoresis with inductively coupled plasma-mass spectrometry, Fresen. J. Anal. Chem. 364 (1999) 452-456.

[62] R. Łobiński, I.R. Pereiro, H. Chassaigne, A. Wasik, J. Szpunar, Elemental speciation and coupled techniques-towards faster and reliable analyses: Plenary lecture, J. Anal. At. Spectrom. 13 (1998) 859-867.

[63] K.E. Lawrence, G.W. Rice, V.A. Fassel, Direct liquid sample introduction for flow injection analysis and liquid chromatography with inductively coupled argon plasma spectrometric detection, Anal. Chem. 56 (1984) 289-292. 
[64] K.E. LaFreniere, V.A. Fassel, D.E. Eckels, Elemental speciation via high-performance liquid chromatography combined with inductively coupled plasma atomic emission spectroscopic detection: Application of a direct injection nebulizer, Anal. Chem. 59 (1987) 879-887.

[65] H. Chassaigne, J. Szpunar, The coupling of reversed-phase HPLC with ICP-MS in bioinorganic analysis, Analusis 26 (1998) M48-M51.

[66] J.A. McLean, H. Zhang, A. Montaser, A Direct Injection High-Efficiency Nebulizer for Inductively Coupled Plasma Mass Spectrometry, Anal. Chem. 70 (1998) 1012-1020.

[67] A.W. Boorn, R.F. Browner, Effects of organic solvents in inductively coupled plasma atomic emission spectrometry, Anal. Chem. 54 (1982) 1402-1410.

[68] G. Raber, R. Raml, W. Goessler, K.A. Francesconi, Quantitative speciation of arsenic compounds when using organic solvent gradients in HPLC-ICPMS, J. Anal. At. Spectrom. 25 (2010) 570-576.

[69] D.T.T. Nguyen, D. Guillarme, S. Rudaz, J.L. Veuthey, Fast analysis in liquid chromatography using small particle size and high pressure, J. Sep. Sci. 29 (2006) 1836-1848.

[70] M. Nowak, A. Seubert, Ultra-trace determination of bromate in drinking waters by means of microbore column ion chromatography and on-line coupling with inductively coupled plasma mass spectrometry, Anal. Chim. Acta 359 (1998) 193-204.

[71] A. Tangen, R. Trones, T. Greibrokk, W. Lund, Microconcentric nebulizer for the coupling of micro liquid chromatography and capillary zone electrophoresis with inductively coupled plasma mass spectrometry, J. Anal. At. Spectrom. 12 (1997) 667-670.

[72] L. Bendahl, S.H. Hansen, B. Gammelgaard, S. Sturup, C. Nielsen, Hyphenation of ultra performance liquid chromatography (UPLC) with inductively coupled plasma mass spectrometry (ICP-MS) for fast analysis of bromine containing preservatives, J. Pharm. Biomed. Anal. 40 (2006) 648-652.

[73] K.A. Francesconi, M. Sperling, Speciation analysis with HPLC-mass spectrometry: Time to take stock, Analyst 130 (2005) 998-1001.

[74] C. Smith, B.P. Jensen, I.D. Wilson, F. Abou-Shakra, D. Crowther, High-performance liquid chromatography/inductively coupled plasma mass spectrometry and tandem mass spectrometry for the detection of carbon-containing compounds, Rapid Commun. Mass Spectrom. 18 (2004) 14871492.

[75] L. Bendahl, B. Gammelgaard, O. Jøns, O. Farver, S.H. Hansen, Interfacing capillary electrophoresis with inductively coupled plasma mass spectrometry by direct injection nebulization for selenium speciation, J. Anal. At. Spectrom. 16 (2001) 38-42. 
[76] F. Gritti, G. Guiochon, The current revolution in column technology: How it began, where is it going?, J. Chromatogr. A 1228 (2012) 2-19.

[77] T. Teutenberg, High-Temperature Liquid Chromatography. A User's guide for Method Development, first ed., RSC Publishing, Cambridge, 2010.

[78] S. Mazan, G. Cretier, N. Gilon, J.M. Mermet, J.L. Rocca, Porous graphitic carbon as stationary phase for LC-ICPMS separation of arsenic compounds in water, Anal. Chem. 74 (2002) 1281-1287. 